\title{
Bronisław Wróblewski - Stefan Glaser. Sprawa katedr prawa i procesu karnego na Wydziale Prawa i Nauk Spotecznycb Uniwersytetu Stefana Batorego w Wilnie
}

\begin{abstract}
Bronisław Wróblewski and Stefan Glaser. The Case of the Departments of Criminal Law and Criminal Procedure at the Faculty of Law and Social Sciences of the Stefan Batory University in Vilnius

The article sets out to present the history of the departments of Criminal Law and Criminal Procedure at the Faculty of Law and Social Sciences of the Stefan Batory University in Vilnius through the prism of the two professors Bronisław Wróblewski and Stefan Glaser. They differed in almost everything (except the place of employment); place of birth, almae matres, and above all the way of pursuing academic passion. Unfortunately, their relationship was significantly affected by their differences in the field of politics too. Wróblewski adamantly believed that criminal law and procedure should be lectured and researched separately, whereas Glaser felt otherwise, perhaps on account of his practical experience. The disputes between both of them concerned inter alia Glaser's professorship appointment and his election to be dean, the reassignment of the academic tasks of their departments, and last but not least - granting them full professorships.
\end{abstract}

Keywords: Stefan Batory University in Vilnius, Faculty of Law and Social Sciences, Bronisław Wróblewski, Stefan Glaser, criminal law, criminal procedure, history of academia, history of law

Słowa kluczowe: Uniwersytet Stefana Batorego w Wilnie, Wydział Prawa i Nauk Społecznych, Bronisław Wróblewski, Stefan Glaser, prawo i proces karny, historia nauki, historia prawa

\section{Wstęp}

Chciałbym w niniejszym artykule przybliżyć dzieje katedry (katedr) prawa i procesu karnego na Wydziale Prawa i Nauk Społecznych (WPiNS) Uniwersytetu Stefana 
Batorego w Wilnie (USB) przez pryzmat aktywności dwóch profesorów je piastujących - Bronisława Wróblewskiego i Stefana Glasera. Tekst pokazuje jedynie skromny wycinek drogi naukowej prowadzącej do objęcia przez obu stanowiska profesora prawa karnego (prawa i procesu karnego) oraz późniejszej działalności naukowo-dydaktycznej w ramach fakultetu prawniczego wileńskiej wszechnicy. Mam nadzieję, że wartościowo uzupełnię istniejącą już literaturę naukową ${ }^{1}$.

Obydwaj uczeni zasługują na samodzielne, monograficzne opracowanie. Pierwszy chociażby z powodu bycia prekursorem socjologii wśród prawników ${ }^{2}$. Drugi jako ofiara sanacyjnego reżimu w ogólności, a działalności Janusza Jędrzejewicza jako ministra wyznań religijnych i oświecenia publicznego w szczególności, a także jako uznany specjalista od międzynarodowego prawa karnego, któremu naukowo poświęcił się zwłaszcza po emigracji z Polski w 1939 r. ${ }^{3}$ Obu łączyło zamiłowanie do prawa karnego, przy czym ten pierwszy był tylko (i aż) uczonym, a drugi - z konieczności - również praktykiem $^{4}$. Poza tym dzieliło ich chyba wszystko. Paralela z duetem Krzymuski-Rosenblatt z Uniwersytetu Jagiellońskiego (UJ), do której jeszcze wrócę, nasuwa się sama. Patrząc politycznie, pierwszy był zwolennikiem, a na pewno sympatykiem, Józefa Piłsudskiego i jego obozu; czy również sanacji i obozu pomajowego - tego nie jestem w stanie autorytatywnie stwierdzić. Drugi z bohaterów był tej opcji zdecydowanym przeciwnikiem i jednocześnie sympatykiem Frontu Morges.

Jak skonstatował w jednym ze swoich tekstów Józef Koredczuk, nauka i nauczanie procesu karnego w czasach Drugiej Rzeczypospolitej nie doczekały się należytego opracowania $^{5}$. Z zagadnieniem samego prawa karnego, jego kodyfikacji itd. jest podobnie ${ }^{6}$. Powstało szereg opracowań przyczynkarskich, ale nadal czekamy na pełną naukową biografię Juliusza Makarewicza. Cały świat prawniczy - praktycy i teoretycy - uznaje go, słusznie przecież, za jednego z najwybitniejszych polskich karnistów. Wyrosło wokół tej postaci tyle mitów i stereotypów, że trudno znaleźć już między nimi prawdziwego Makarewicza. Zatem, aby nie popełnić już tych grzechów zaniechania, przejdźmy do tekstu właściwego dotyczącego Wróblewskiego i Glasera.

${ }^{1}$ Zob. Dąbrowski, Mutationes in doctrina iuris; Piechnik, Puchowski, Księga pamiątkowa; Księga pamiatkowa ku uczczeniu CCCL rocznicy powstania; Machovenko, Law Faculty of Vilnius University; Przeniosło, „Profesorowie Wydziału Prawa”; Przeniosło, Przeniosło, „Studia prawnicze na Uniwersytecie Stefana Batorego"; Tarkowski, Wydziat Prawa i Nauk Społecznych (tam przywoływane też inne teksty tego autora).

${ }^{2}$ Zob. Kolarzowski, „Bronisław Wróblewski”, 33 i n..; Kolarzowski, „Definicja i funkcje polityki kryminalnej", 23 i n.

${ }^{3}$ Zob. Smolana, Stownik biograficzny polskiej stużby zagranicznej 3, 46. Żukowski, „Pracownicy i absolwenci Uniwersytetu Jagiellońskiego", 46.

${ }^{4}$ Redzik, Kotliński, Historia adwokatury, 236-7.

${ }^{5}$ Koredczuk, „Nauka i nauczanie procesu karnego”, 117. Zob. też: Opałek, Wolter, Nauka filozofii.

${ }^{6}$ Lityński, Wydziat Karny Komisji Kodyfikacyjnej. 


\section{Krótki rys biograficzny Bronisława Wróblewskiego oraz Stefana Glasera. Droga do katedry uniwersyteckiej}

Dnia 13 listopada 1888 r. w mieście będącym stolicą jednej z guberni Imperium Rosyjskiego, Twerze, w rodzinie Józefa, szlachcica ${ }^{7}$ i Julii de domo Smolechowskiej przyszedł na świat syn, któremu na chrzcie w tamtejszym rzymskokatolickim kościele parafialnym nadano - jedno (w przeciwieństwie do panującego wówczas zwyczaju) - imię Bronisław ${ }^{8}$. Z biegiem lat rodzina przeniosła się do Warszawy, gdzie ojciec pracował jako referent służby ruchu i przynajmniej w 1910 r. zamieszkiwali przy ulicy Wspólnej 629. Tam młody Bronisław Józefowicz uczęszczał do Zakładu Naukowego Filologicznego ośmioklasowego generała Pawła Chrzanowskiego. Maturę rosyjską uzyskał jednak w trybie eksternistycznym w V Gimnazjum, także w stolicy Kraju Przywiślańskiego ${ }^{10}$, w czerwcu 1910 r. ${ }^{11}$

W tym roku Wróblewski przybył do Krakowa. Z jakich powodów tutaj trafił, trudno orzec. Niemniej, mimo że pobyt pod Wawelem okazał się epizodem (wysłuchał tylko semestru zimowego roku akademickiego 1910/11), w życiu naszego bohatera odnotować należy trzy związane z tym faktem znamienne informacje. Pierwszą było to, że Wróblewski został słuchaczem zwyczajnym na Wydziale Filozoficznym. Tam zapisał się na następujące przedmioty: Mickiewicz w świetle nowszych źródet (Tadeusz Garbowski), Historia literatury polskiej (Ignacy Chrzanowski), Zarys historii filozofii (Władysław Heinrich), Rafael (Jerzy Mycielski), Nietzsche a przeszłość ludzkości

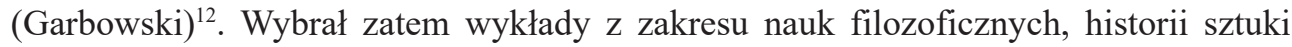
i literatury. Drugim ważnym wydarzeniem było uczestnictwo w zamieszkach studenckich, do jakich doszło na uniwersytecie na przełomie 1910 i 1911 r. w związku z pewną nominacją na katedrę chrześcijańskich nauk społecznych. Pod tą, może niewiele dziś mówiącą nazwą, kryje się ni mniej, ni więcej tylko przedmiot szeroko obecnie wykładany na uczelniach i należący do jednego z najbardziej obleganych kierunków przez kandydatów na studia, a mianowicie socjologia. Młodzieży akademickiej krakowskiej wszechnicy nie tyle nie podobało się, iż namaszczony Najwyższym Postanowieniem profesor pochodził z Poznania. Problem polegał na tym, że był księdzem, a katedra została przypisana Wydziałowi Teologicznemu. Obawiano się, iż wiedza głoszona z niej przez Kazimierza Zimmermanna, bo o niego tutaj chodziło, zostanie ograniczona do jedynie słusznej, zgodnej z doktryną Kościoła katolickiego. I tu dochodzimy do faktu trzeciego - zaangażowania Wróblewskiego w protesty, za co 25 stycznia 1911 r. i na

${ }^{7}$ LCVA, f. 175, op. 1(I)Bb, spr. 786, curriculum vitae z 31 stycznia 1919 r.

${ }^{8}$ Ibid.

${ }^{9}$ AUJ, S II 226b; WF II 359.

${ }^{10}$ LCVA, f. 175, op. 1(I)Bb, spr. 786, curriculum vitae z 31 stycznia 1919 r.

${ }^{11}$ Ibid., poświadczenie z 8 października 1920 r. Poświadczenie wydał również W. Komarnicki wówczas profesor USB, a prywatnie kolega B. Wróblewskiego z warszawskiego gimnazjum i studiów uniwersyteckich w Dorpacie. Zob. ibid., poświadczenie z 1 października $1920 \mathrm{r}$.

12 AUJ, S II 226b; S II 515; WF II 359. Został wpisany w kwesturze pod numerem 3244, pobrano opłatę za immatrykulację w wysokości 10 koron oraz opłatę biblioteczną 2 korony. W katalogu wydziałowym nie ma adnotacji dziekańskich, z czego możemy wnioskować, iż semestr nie został zaliczony. Zob. Barcik i in., Corpus Studiosorum 3, 677-8. 
podstawie uchwały Senatu Akademickiego UJ udzielono mu tzw. nagany z zagrożeniem wydalenia (cum consilio abeundi) za udział w nielegalnym wiecu w dniu 29 listopada 1910 r., będącym częścią tzw. Zimmermaniady. To wszystko, co wyżej przedstawiłem choć prawdopodobnie to konstatacja zbytnio na wyrost - może już jednak świadczyć o rodzących się wówczas zainteresowaniach prawniczych i socjologicznych.

Wróblewski opuścił Kraków, i studia, tym razem prawnicze, podjął na obleganym wówczas przez Polaków Uniwersytecie w Dorpacie (Juriewie), obecnie noszącym nazwę Tartu i znajdującym się w Estonii ${ }^{13}$. Po studiach na Wydziale Prawa uzyskał 29 maja 1915 r. możliwość uzyskania dyplomu kandydata praw, co nastąpiło 7 marca 1916 r. po ,„[...] aprobacie dysertacji zatytułowanej «Przestępstwa tłumu»"14. Wróblewskiemu zostało nawet zaproponowane stanowisko asystenta przy katedrze prawa karnego, ale z powodu wybuchu wojny i ,[...] niemożności znalezienia zarobku w Dorpacie wśród powstałej drożyzny stało się [to] niemożliwem". Odcięcie od kraju rodzinnego spowodowało, że udał się do Moskwy ${ }^{15}$. Od 1916 r. był asystentem na Wydziale Prawa Uniwersytetu w Moskwie u profesora Poznyszewa ${ }^{16}$.

W Moskwie Wróblewski pracował w Komitecie Polskim jako konsultant prawny od października 1916 r. do października 1917 r. ${ }^{17}$ Od września 1917 r. do czerwca 1918 r. sprawował również funkcję dyrektora ośmioklasowej Szkoły Męskiej Polskiej Macierzy Szkolnej w Moskwie. W tym samym niemal czasie (roku szkolnym 1917/18) był wykładowcą na kursach dla pracowników administracyjno-skarbowych organizowanych przez stowarzyszenie prawników i pracowników sądowych w Moskwie ${ }^{18}$. Wybuch rewolucji - najpierw lutowej, a następnie październikowej w 1917 r. - i związana z tymi, lecz nie tylko, wydarzeniami zmiana sytuacji politycznej (jak odzyskanie przez Polskę niepodległości) spowodowały, że Wróblewski wrócił do ojczystego kraju. Na początku 1919 r. został najpierw pełniącym obowiązki referenta (podanie złożył 31 stycznia 1919 r. ${ }^{19}$, a przysięgę 7 lutego $1919 \mathrm{r}^{20}$ ), a następnie został referentem i starszym referentem w Ministerstwie Spraw Wewnętrznych w Warszawie (MSW). Stanowisko formalnie pełnił od 1 lutego 1919 r. do 30 września 1921 r. ${ }^{21}$ Na przełomie 1919 i 1920 r. Wróblewski bardzo poważnie zachorował i musiał poddać się operacji. Szef sekcji administracyjnej

13 Cyuńczyk, „Wydział Prawa Uniwersytetu w Dorpacie”, 181-91.

${ }^{14}$ LCVA, f. 175, op. 1(I)Bb, spr. 786, odpis dyplomu z 7 marca 1916 r.; notatka z 28 (15) czerwca 1918 r.; f. 175, spr. 2(VI)B, spr. 55, wniosek z 4 czerwca 1921 r.

15 LCVA, f. 175, spr. 2(VI)B, spr. 55, wniosek z 4 czerwca $1921 \mathrm{r}$.

${ }^{16}$ LCVA, f. 175, op. 1(I)Bb, spr. 786, curriculum vitae z 31 stycznia 1919 r.; f. 175, spr. 2(VI)B, spr. 55, wniosek z 4 czerwca $1921 \mathrm{r}$.

17 Według Komisji Weryfikacyjnej, która zaliczyła mu czas pracy jako konsultanta Komitetu Polskiego Pomocy Ofiarom Wojny w Moskwie, pracował od 1 sierpnia 1916 do 14 maja 1918 r. Zob. LCVA, f. 175, op. 1(I)Bb, spr. 786, pismo z MSW z 19 listopada 1920 r.

18 Ibid., wykaz stanu osobowego, k. 5; curriculum vitae z 31 stycznia 1919 r.

19 Ibid., podanie z 31 stycznia 1919 r.

${ }^{20}$ Obejmując służbę w Ministerstwie Spraw Wewnętrznych Państwa Polskiego przyrzekam uroczyście: Dobro Państwa Polskiego oraz dobro publiczne mieć zawsze przed oczyma; Republice Polskiej wierności dochować; Narodowi Polskiemu wiernie służyć, wszystkich obywateli kraju w równem mając zachowaniu; przepisów prawa strzec pilnie, obowiązki swoje spełniać gorliwie i sumiennie, polecenia przełożonych wykonywać dokładnie, tajemnicy urzędowej dochować. Zob. ibid., przysięga z 7 lutego 1919 r. Przysięgę jako referent złożył w obecności ministra Wojciechowskiego 30 marca 1920 r. Zob. ibid., przysięga z 30 marca $1920 \mathrm{r}$.

${ }^{21}$ Ibid., wykaz stanu osobowego. 
MSW zwracał się do kierownika resortu 20 czerwca 1920 r., iż wprawdzie do służby wojskowej Wróblewski się nie nadaje, ale jest bardzo użytecznym pracownikiem. Szef sekcji dodatkowo podał, że nie widzi powodu, aby wzywać Wróblewskiego do złożenia deklaracji o służbie ochotniczej, co i tak by niezwłocznie uczynił. Byłaby to deklaracja czysto demonstracyjna. Pismo to zostało wysłane, aby zabezpieczyć Wróblewskiego od ewentualnych zarzutów, że uchyla się od służby, co nie miało pokrycia w rzeczywistości ${ }^{22}$. Wymiana tych oficjalnych pism związana była z wymogiem, który - oddolnie, na wniosek kilku senatów uniwersyteckich, w tym UJ i Uniwersytetu Jana Kazimierza (UJK) - wprowadziła Rada Ministrów w postaci rozporządzenia, a dotyczył on udokumentowania odbycia wspomnianej wcześniej służby w okresie walki o niepodległość Rzeczypospolitej ${ }^{23}$. W 1920 r. Wróblewski został powołany do wykładów w Wolnej Wszechnicy Polskiej w Warszawie w zastępstwie Emila Stanisława Rappaporta. Prowadził w jednym semestrze wykład z prawoznawstwa karnego XX w., a w drugim wykładał psychologię karną ${ }^{24}$.

Pod koniec 1921 r. Wróblewski zmienił stan cywilny. W warszawskim kościele parafialnym Świętej Barbary 26 listopada 1921 r., o godzinie 6 po południu zawarł związek małżeński z Krystyną Marią Karoliną Hirschberg (wówczas siedemnastoletnią), córką Karola i Marianny z domu Jędrzejewskiej ${ }^{25}$. Z tego związku urodzili się dwaj synowie: Jerzy Bronisław (ur. 5 października 1925 r.) ${ }^{26}$ oraz Andrzej Krystyn (ur. 15 maja 1927 r. $)^{27}$, który został znanym i cenionym malarzem. Na marginesie tylko dodam, iż Krystyna de domo Hirschberg Wróblewska (1904-1994) po ukończeniu Wydziału Sztuk Pięknych USB ${ }^{28}$ była po 1945 r. (mieszkając już w Krakowie) znaną artystką i grafikiem, autorką ekslibrisów, wykładowcą Politechniki Krakowskiej29. Starszy syn (zm. 31 maja 1990 r.) był teoretykiem prawa, doktorem praw UJ, profesorem prawa, kierownikiem Katedry Teorii Państwa i Prawa na Uniwersytecie w Łodzi oraz rektorem tej uczelni ${ }^{30}$, a młodszy (zm. 23 marca 1957 r.) - absolwentem UJ i Akademii Sztuk Pięknych w Krakowie (której był również pracownikiem) oraz malarzem ${ }^{31}$.

W 1922 r. Wróblewski powrócił na UJ. W zasadzie z jednego tylko powodu, a mianowicie nostryfikacji swojego stopnia kandydata praw. Być może - jeżeli weźmiemy pod uwagę wybór uczelni - to zadziałały tutaj względy prestiżowe lub presja czy sugestia kolegi Wacława Komarnickiego, który swój dyplom kandydata praw z Dorpatu z 1914 r. nostryfikował jak doktorat praw UJ 31 sierpnia 1920 r. $^{32}$. W swoim podaniu

${ }^{22}$ Ibid., pismo szefa sekcji administracyjnej z 20 lipca $1920 \mathrm{r}$.

${ }^{23}$ AAN, Protokoły Posiedzeń Rady Ministrów, t. VII, posiedzenie z 18 września 1919 r., k. 457-8. Zob. Pilch, Rzeczpospolita Akademicka, 24-6; Tomaszewski, „Rząd Rzeczypospolitej Polskiej wobec projektu”, 116-17.

${ }^{24}$ LCVA, f. 175, spr. 2(VI)B, spr. 55, wniosek z 4 czerwca 1921 r. Zob. Baranowski, Alternatywna edukacja.

25 LCVA, f. 175, op. 1(I)Bb, spr. 786, odpis świadectwa małżeństwa z 29 listopada $1921 \mathrm{r}$.

${ }^{26}$ Ibid., odpis świadectwa chrztu z 24 lutego $1931 \mathrm{r}$.

27 Ibid., odpis świadectwa chrztu z 7 stycznia 1928 r.

28 Ibid., zaświadczenie z 9 stycznia $1935 \mathrm{r}$.

29 Kozłowska, Życie dtutem wyżłobione.

${ }^{30}$ Kita, Pytlas, Profesorowie Uniwersytetu Łódzkiego, 231-3. Lewandowski, Zirk-Sadowski, „Jerzy Wróblewski", 92-5.

31 Michalski, Andrzej Wróblewski.

32 Żukowski, Dzieje Wydziału Prawa... Źródła, 63. 
do dziekana Wydziału Prawa UJ z 19 września 1922 r. Wróblewski napisał, że pragnie przystąpić do habilitacji, a nie posiada stopnia doktora praw, prosi więc o uznanie studiów w Dorpacie i dyplomu pierwszego stopnia ,[...] za odpowiadający tamtejszemu doktoratowi praw"33. Wymóg taki wprowadziła ustawa o szkołach akademickich z 13 lipca 1920 r. $^{34}$, ale była to - w tym wypadku - czysta formalność i Wróblewski mógł tę sprawę załatwić przez Radę WPiNS ${ }^{35}$. Niezależnie od tego jako urzędnik MSW i zastępca profesora w Wilnie wniósł do Prześwietnego Wydziału Prawa UJ podanie o nostryfikację stopnia kandydata praw. 23 września 1922 r. referat został przez dziekana Tadeusza Dziurzyńskiego poruczony Edmundowi Krzymuskiemu, a ten przedstawił go na posiedzeniu Rady Wydziałowej 9 grudnia 1922 r. Po dyskusji Rada uznała dyplom Wróblewskiego za równorzędny ze stopniem doktora do celów habilitacyjnych ${ }^{36}$. Tym samym rektor UJ nostryfikował, czyli ni mniej, ni więcej na oryginale dyplomu dorpackiego uczynił piórem adnotację, iż jest on równy i tożsamy z dyplomem doktorskim uzyskanym na UJ, a jego okaziciel ma prawo posługiwać się stopniem doktora praw najstarszej polskiej uczelni i przystąpić do habilitacji. 11 grudnia 1922 r. do zainteresowanego zostało wysłane pismo wraz z decyzją i złożonymi załącznikami ${ }^{37}$.

$$
* * *
$$

Młodszy o lat siedem Stefan Glaser urodził się w galicyjskim mieście powiatowym, Tarnowie, 20 stycznia 1895 r., w rodzinie inteligenckiej. Dziadek ze strony ojca, Langold, był doktorem medycyny, a ojciec drugiego z omawianych uczonych, Ludwik, po studiach na uniwersytetach w Wiedniu i we Lwowie, po złożeniu egzaminów ścisłych na UJ, został 21 grudnia 1881 r. wypromowany na doktora praw i w swoim dorosłym życiu był adwokatem. Matką Stefana była Berta (Berthea) de domo Jampolska.

Młody Stefan Antoni uczył się w gimnazjach jako prywatysta. Najpierw w I Gimnazjum w Tarnowie, do którego uczęszczał do klas I-IV: 1906/07-1909/10. Następnie, po złożeniu egzaminów potwierdzających wiedzę z zakresu klasy V i częściowo VI, został przyjęty do Gimnazjum im. Adama Mickiewicza we Lwowie, do którego uczęszczał od drugiego semestru klasy VI do klasy VIII w latach szkolnych 1911/12 (sem. II 1913/14). Złośliwa młodzież naszywkę na czapkach studentów - bo tak dawniej okre-

33 AUJ, WP II 542, podanie B. Wróblewskiego z 19 września $1922 \mathrm{r}$.

34 Ustawa o szkołach akademickich z 1920 r. (Dz.U.R.P. 1920, nr 72, poz. 494).

35 Można tu przywołać habilitację Jerzego Landego w UJ. Zastępca profesora teorii i filozofii prawa USB przeszedł całą procedurę habilitacyjną bez najmniejszego problemu i 25 maja 1925 r. Rada Wydziałowa nadała mu prawo wykładania i tytuł docenta teorii i filozofii prawa UJ. Jednak 10 czerwca 1925 r. członkowie Rady Wydziałowej musieli spotkać się ponownie, gdyż, ,[...] na posiedzeniu Rady Wydziału Prawa z dnia 25 V [1925], na którym uchwalono nadać p[anu] Jerzemu Landemu prawo wykładania w zakresie teorii i filozofii prawa, z uwolnieniem go w myśl art[ykułu] 55 ust[awy] o szk[ołach] akademickich od dwóch dalszych aktów habilitacji, nie załatwiono kwestii uwolnienia kandydata od obowiązku wykazania się tytułem doktorskim. Z uwagi na to Dziekan wnosi, aby Rada, dla utrzymania aktu habilitacyjnego w zgodzie z ustępem końcowym art[ykułu] 52 ust[awy] o szk[ołach] akad[emickich] obecnie uwolniła p[ana] Jerzego Landego w uwzględnieniu jego dotychczasowej wyjątkowo wybitnej działalności naukowej, od obowiązku wykazania się tytułem doktorskim. Uchwalono jednomyślnie zgodnie z wnioskiem Dziekana”. Zob. Żukowski, Dzieje Wydziału Prawa... Źródła, 192-3.

36 Żukowski, Dzieje Wydziału Prawa... Źródła, 144.

${ }^{37}$ AUJ, WP II 542, brudnopis odpowiedzi z 11 grudnia 1922 r. 
ślano uczniów tego typu szkół - z tego gimnazjum, a mianowicie inicjały A.M., odczytywała jako - Akademia Matołków. Z naszym bohaterem aż tak źle najpewniej nie było, gdyż po zdaniu egzaminów 10 czerwca 1914 r. otrzymał świadectwo maturalne ${ }^{38}$. Podjął wówczas prawnicze studia uniwersyteckie, idąc za przykładem płynącym z domu, a na pewno będąc pod wpływem wydarzeń politycznych. Prawo studiował najpierw w mieście nad Dunajem, a następnie kontynuował je nad Pełtwią. Taki wybór nie należał li tylko do Glasera. Wybuch Wielkiej Wojny, jak nazwano w czasach późniejszych konflikt zapoczątkowany w 1914 r., spowodował m.in. konieczność zamknięcia Uniwersytetu Franciszka I i ewakuacji profesorów ze Lwowa. Glaser w Alma Mater Rudolphina spędził jako słuchacz zwyczajny cztery semestry w latach akademickich 1914/15 - 1915/16 i uzyskał poświadczenie ich ukończenia (świadectwo odejścia). W Wiedniu przed Państwową Komisją Egzaminów Prawniczych zdał 2 marca 1916 r. pierwszy egzamin rządowy z przedmiotów historyczno-prawnych. Ten dokument, łącznie z przytoczonym już świadectwem odejścia, umożliwiły mu wpisanie się na wszechnicę lwowską, gdzie na Wydziale Prawa i Umiejętności Politycznych w latach 1916/17 sem. II - 1917/18 dokończył edukację w zakresie prawa i uzyskał 31 lipca 1918 r. absolutorium. Tutaj należą się Czytelnikowi wyjaśnienia. Liczba siedmiu semestrów, bo tylu w trakcie studiów wysłuchał Glaser, a nie ośmiu, jak wynikało z ordynacji studiów, nie jest błędem. Nasz bohater od 23 sierpnia 1916 r. do 1 listopada 1918 r. służył w armii austriackiej. Następnie został żołnierzem Wojska Polskiego w randze podchorążego audytora i przydzielono go do Korpusu Sędziów. Tu służył od 23 listopada 1918 r. do 9 listopada 1920 r. Czas służby wojskowej mógł zostać, na podstawie reskryptu Ministerstwa Wyznań i Oświaty z 18 lutego 1916 r., zaliczony słuchaczom studiów prawniczych do pierwszego lub drugiego okresu ich studiów. Tak właśnie było w przypadku Glasera.

Uzyskanie absolutorium otworzyło Glaserowi możliwość przystąpienia do egzaminów ścisłych (rygorozów) na stopień doktora praw, do których zgłosił się według wskazanej kolejności i otrzymał następujące oceny cząstkowe i łączne:

W roku szkolnym 1917/18, kiedy dziekanem był Kamil Stefko:

Rygorozum I (iuridicum) - 25 maja 1918, a egzaminowali: Piotr Stebelski (valde bene); Marceli Chlamtacz (valde bene); Aleksander Doliński (sufficienter); Kamil Stefko (valde bene); przyjęte jednomyślnie, a jako valde bene większością głosów; świadectwo wydano 20 lipca 1918 r.

Rygorozum II (historicum) - 8 sierpnia 1918, a egzaminowali Oswald Balzer (valde bene); Władysław Abraham (valde bene); Marceli Chlamtacz (sufficienter); Przemysław Dąbkowski (valde bene); Kamil Stefko (valde bene); przyjęte jednomyślnie, a jako valde bene większością głosów; świadectwo wydano 8 sierpnia [1918 r.];

W roku szkolnym 1918/19, kiedy dziekanem był Stanisław Starzyński:

Rygorozum III (politicum) - 25 września 1918, a egzaminowali Stanisław Głąbiński (valde bene); Stanisław Starzyński (sufficienter); Aleksander Doliński (valde bene); Ernest Till (valde bene); przyjęte jednomyślnie, a jako valde bene większością głosów; świadectwo wydano 25 września $1918 \mathrm{r}^{39}$

Po pomyślnie złożonych egzaminach Glaser 5 października 1918 r. został wypromowany na doktora praw. Dodatkowo, tym razem przed lwowską Komisją Rządowych

\footnotetext{
38 AUJ, WP II 138, teczka habilitacyjna S. Glasera, odpis świadectwa dojrzałości.

39 DALO, f. 26, op. 15, spr. 502, poz. 252, k. 253.
} 
Egzaminów Prawniczych, zdał pozostałe dwa egzaminy: egzamin sądowy - 24 maja 1918 r. oraz egzamin z nauk politycznych - 1 października 1918 r. $^{40}$

U progu niepodległości, we Lwowie, rozpoczynał Glaser swoją karierę w adwokaturze - początkowo jako kandydat adwokacki we Lwowie w kancelarii swojego ojca, gdzie praktykował od 8 października 1918 r. ${ }^{41}$

Rok 1920 był przełomowy w życiu Glasera. Najpierw został referentem w Wydziale Ustawodawczym Departamentu Sprawiedliwości Ministerstwa byłej Dzielnicy Pruskiej (13 stycznia - 31 sierpnia 1920 r.), następnie sędzią śledczym Sądu Okręgowego w Lublinie (1 września 1920 - 31 marca 1922 r.). Dnia 4 marca 1920 r. wniósł w UJ podanie o udzielenie venia legendi z zakresu prawa karnego materialnego i formalnego. Półtora miesiąca później, 20 kwietnia 1920 r., we Lwowie stanął na ślubnym kobiercu. Wybranką była urodzona w Tarnopolu Marta Helena de domo Broniewska (córka Alfreda Karola i Michaliny Kamieniobrodzkiej). Z tego związku narodziła się córka Krystyna Maria (ur. 4 września 1922 r.) ${ }^{42}$.

Wróćmy do sprawy habilitacji. Podstawą podania były dwie rozprawy: Przyczynek do nauki o udziale w przestepstwie (Lwów 1919) oraz Kilka uwag o podstawie prawnej lekarskiej działalności (Lwów 1920). Kolegium Profesorów Wydziału Prawa 2 czerwca 1920 r., po stwierdzeniu braku przeszkód osobistych co do wdrożenia habilitacji, wyznaczyło referentów: Krzymuskiego i Stanisława Kutrzebę ${ }^{43}$. Dnia 28 stycznia 1921 r. drugi z nich, który w tym roku akademickim pełnił funkcję dziekana, poinformował Radę Wydziałową, iż z powodu zajęć związanych z pełnionymi obowiązkami nie może podjąć się napisania referatu. Rada powołała zatem na drugiego referenta Józefa Reinholda ${ }^{44}$. Referat był gotowy i został przedstawiony na posiedzeniu Rady 9 marca 1921 r. Krzymuski wniósł o uznanie przedstawionych prac za dostateczną podstawę dalszych aktów habilitacyjnych. Po zaprezentowaniu swojego referatu Reinhold przyłączył się do wniosku. Niestety nie znamy treści obu referatów. W dyskusji, która miała miejsce później, zabrali głos aż czterej profesorowie: Stanisław Estreicher, Stanisław Wróblewski, Władysław Leopold Jaworski oraz dziekan S. Kutrzeba. Ostatecznie wniosek został przyjęty wobec sprzeciwu jednej osoby - właśnie Kutrzeby ${ }^{45}$. Kolokwium zostało wyznaczone na 25 kwietnia 1921 r. i po jego przeprowadzeniu przez dwóch referentów zostało przyjęte jednomyślnie ${ }^{46}$. Wykład habilitacyjny, który został wybrany z trzech przedstawionych, na temat: „O zastosowaniu ustawy karnej pod względem czasu i miejsca” odbył się nazajutrz. Na posiedzeniu Rady pod przewodnictwem Kutrzeby stawili się: Krzymuski, Franciszek Ksawery Fierich, Fryderyk Zoll młodszy, Jaworski, Stanisław Wróblewski, Estreicher, Michał Rostworowski, Józef Brzeziński, Adam Krzyżanowski, Kazimierz Władysław Kumaniecki, Stanisław Gołąb oraz delegat docentów - Reinhold. Po wygłoszeniu wykładu przystąpiono do głosowania nad udzieleniem venia legendi. Wniosek obu referentów został przyjęty większością głosów,

40 Żukowski, Profesorowie Wydziału Prawa 2, 121-3.

41 Redzik, „Glaser Stefan Antoni”, 113-5.

42 Żukowski, Profesorowie Wydziału Prawa 2, 121-3. Zob. Cieślak, „Stefan Glaser”, 104. Pluta, „Autorytety prawnicze", 229-30.

43 Żukowski, Dzieje Wydziału Prawa... Źródła, protokół z 2 czerwca 1920 r., 65.

44 Ibid., protokół z 28 stycznia 1921 r., 93.

45 Ibid., protokół z 9 marca 1921 r., 95.

${ }^{46}$ Ibid., protokół z 25 kwietnia 1921 r., 113. 
wobec sprzeciwu już nie tylko dziekana, ale również Estreichera, Brzezińskiego oraz Taubenschlaga. Niemniej Glaser otrzymał prawo wykładania w zakresie prawa karnego oraz tytuł docenta $\mathrm{UJ}^{47}$. Po latach Taubenschlag zapisał:

Ponadto habilitowano - jak się wyrażano „na eksport” - Glasera, [Franciszka lub Józefa Jana] Bossowskiego, [Cezarego] Berezowskiego, [Józefa] Rafacza i innych. Utarł się bowiem zwyczaj, że nowozałożone uniwersytety, jak poznański i wileński - nie mając odpowiednich sił, zaczęły się zwracać o pomoc do uniwersytetu krakowskiego, a ten nie posiadając odpowiednich kandydatów na prędce habilitował ludzi często zupełnie niewykwalifikowanych ${ }^{48}$.

Czy również za niewykwalifikowanego Taubenschlag uważał Glasera - trudno orzec. Być może na powyższe stwierdzenie oraz opór Kutrzeby i innych członków Rady Wydziałowej wpływ miał fakt, że według austriackich przepisów powinny upłynąć dwa lata od daty promocji doktorskiej, aby kandydat mógł złożyć podanie o habilitację. I tutaj znajdujemy w źródłach potwierdzenie konstatacji Taubenschlaga, gdyż Uniwersytet w Lublinie pragnął mianować Glasera profesorem nadzwyczajnym i chciał, aby uczony posiadał habilitację uzyskaną w Krakowie lub we Lwowie. Aby obejść ten dwuletni termin, sam zainteresowany i rektor UJK wystosowali do Krzymuskiego list. Profesor prawa karnego UJ odpisał, że zwolnienie ,z terminów” kandydata nie leży w gestii jednego profesora, lecz całego wydziału, a po rozmowie z kolegami wie, że wydział jest sceptyczny wobec tej decyzji, podobnie jak on sam. Dodał: „,...] tylko z wielką trudnością mógłbym się zgodzić na habilitowanie młodego człowieka w tym jedynym celu, aby mu ułatwić zbyt szybki przeskok z ławy uczniowskiej na katedrę profesorską". Krzymuski pytał, który z uniwersytetów - lwowski czy krakowski - miałby się poczuwać do wdrożenia nadzwyczajnej procedury. Zauważał również, że bez ,zbyt rażącej nieformalności” Uniwersytet w Lublinie może powołać Glasera na suplenta, „[...] aż do czasu nabycia przez niego prawa do złożenia podania o venia legendi"49. Niemniej Krzymuski nie był tej kandydaturze aż tak przeciwny jak można by sądzić, o czym świadczy list tegoż z 12 kwietnia 1920 r., wskazujący na Glasera jako odpowiedniego kandydata do objęcia katedry w Lublinie ${ }^{50}$. Za Krakowem jako miejscem habilitacji a nie Lwowem, gdzie Glaser ukończył studia - przemawiał jeszcze jeden fakt. Stebelski mistrz naszego bohatera, u którego składał na Uniwersytecie we Lwowie egzaminy - nie miał silnej pozycji na wydziale, a takową na pewno miał Makarewicz, który raczej Glaserowi nie sprzyjał. Mniemam tak na podstawie listu, w którym późniejszy twórca kodeksu karnego stwierdził, że nie widzi - w przeciwieństwie do przywołanego wyżej Krzymuskiego - kandydata na katedrę lubelską, a „,...] są to skutki pospiesznego tworzenia uniwersytetów" ${ }^{51}$.

Ostatecznie Ministerstwo Wyznań Religijnych i Oświecenia Publicznego (MWRiOP) 6 lipca 1921 r. zatwierdziło uchwałę Rady Wydziałowej, popartą uchwałą Senatu Akademickiego UJ z 24 czerwca 1921 r. $^{52}$. Glaser nie wykładał jednak na UJ jako do-

\footnotetext{
47 Żukowski, Profesorowie Wydziału Prawa 2, 121-3.

48 Taubenschlag, Pamiętnik.

49 AKUL, sygn. A-16, list E. Krzymuskiego z 14 stycznia 1919 r.

50 Ibid., list E. Krzymuskiego z 12 kwietnia 1920 r.

51 Żukowski, Dzieje Wydziału Prawa, 444; Żukowski, Dzieje Wydziału Prawa... Źródła, 121 i nast.

52 Ibidem.
} 
cent. Zgodnie z obowiązującym prawem złożył podanie o urlop, który corocznie - w latach akademickich od 1921/22 do 1923/24 - był odnawiany ${ }^{53}$.

\section{3. (I) Katedra prawa i procesu karnego}

Rada Wydziałowa WPiNS USB zaproponowała Bronisława Wróblewskiego na katedrę 4 czerwca 1921 r. Zanim do uchwały doszło, Komarnicki referował sprawę powołania wykładającego prawo karne. Brał pod uwagę dwóch kandydatów - Wróblewskiego oraz Stanisława Śliwińskiego - i tego pierwszego zaproponował na zastępcę profesora na katedrze, co uchwaliła Rada na rok akademicki 1921/22 $2^{54}$. O takim stanie rzeczy Senat Akademicki USB został poinformowany w piśmie Alfonsa Parczewskiego ${ }^{55}$. We wniosku, po krótkim życiorysie kandydata, przybliżono jego sylwetkę naukową. Napisano, że MSW ceni Wróblewskiego jako zdolnego prawnika i człowieka o nieskazitelnym charakterze. Omówiono jego dorobek, który dawał rękojmię, że kandydat będzie wartościowym nabytkiem dla Wydziału. Wróblewski opracował - jak zapisano - wiele cennych prac, m.in. Przestęstwa ttumu (Wilno 1922) czy ostatnia - co podkreślono we wniosku Przestępstwo (Dziennik Urzędowy Ministerstwa Sprawiedliwości ${ }^{56}$ ) - jest najobszerniejsza i najbardziej cenna, gdyż autor przedstawił w niej, po analizie szeregu teorii przestępstwa, własną tezę:

Nie wchodząc w merytoryczną ocenę tej konstrukcji należy uznać przeprowadzenie jej z punktu widzenia metodologicznego za zupełnie poprawne. Jest to już praca zakrojona na większą miarę. Ogólny wniosek z oceny prac naukowych Wróblewskiego sprowadza się do stwierdzenia faktu, że autor wykazuje w nich erudycję, krytycyzm i zdolność do własnych konstrukcji prawnych ${ }^{57}$.

Na rok akademicki 1921/22 (1 października - 30 września) MWRiOP zatwierdziło Wróblewskiego jako zastępcę profesora na katedrze nadzwyczajnej prawa i procesu karnego ${ }^{58}$. Rada Wydziałowa uchwaliła na posiedzeniu 11 maja 1922 r. wnieść o przedłużenie zastępstwa, co zatwierdził Senat Akademicki 16 czerwca 1922 r. ${ }^{59} \mathrm{Na}$ tym samym posiedzeniu podjęto jeszcze dwie ważne decyzje. Po pierwsze uchwalono, aby ,[...] domagać się nowej katedry procedury karnej”, co rozumieć należy jako podjęcie starań czy zabiegów o kreowanie nowej, drugiej, katedry poświęconej prawu karnemu, w tym

53 Ibidem.

54 AAN, MWRiOP, sygn. 6703, Teczka personalna B. Wróblewskiego; LCVA, f. 175, op. 13, spr. 339, protokół z 4 czerwca 1921 r. Zob. LCVA, f. 175, spr. 2(VI)B, spr. 55, wniosek Rady Wydziałowej z 4 czerwca 1921 r.; Tarkowski, Wydział Prawa i Nauk Społecznych, 97 i nast.

55 LCVA, f. 175, spr. 2(VI)B, spr. 55, odpis pisma A. Parczewskiego z 6 czerwca $1921 \mathrm{r}$.

${ }^{56}$ Dziennik Urzędowy Ministerstwa Sprawiedliwości składał się z dwóch części: urzędowej oraz zawierającej teksty naukowe.

${ }_{57}$ LCVA, f. 175, spr. 2(VI)B, spr. 55, wniosek z 4 czerwca $1921 \mathrm{r}$.

${ }^{58}$ LCVA, f. 175, op. 1(I)Bb, spr. 786, pismo Żorawskiego z 10 sierpnia 1921 r.; f. 175, op. 14, spr. 600, odpis pisma Żorawskiego z 10 sierpnia 1921 r.; f. 175, spr. 2(VI)B, spr. 55, odpis pisma Żorawskiego z 10 sierpnia 1921 r. Zob. Kolarzowski, „Definicja i funkcje polityki kryminalnej”, 23-46.

${ }^{59}$ LCVA, f. 175, op. 1(I)Bb, spr. 786, pismo A. Parczewskiego z 16 czerwca 1922 r.; odpis pisma do MWRiOP z 20 czerwca 1922 r.; f. 175, spr. 2(VI)B, spr. 55, odpis pisma A. Parczewskiego z 16 czerwca 1922 r. 
przypadku procedurze (procesowi). Po drugie powołano komisję celem stałego obsadzenia katedry prawa karnego w składzie dziekan Parczewski, prodziekan Władysław Zawadzki oraz Franciszek Bossowski ${ }^{60}$.

Na marginesie dodam, że w związku z podjęciem wykładów w Wilnie początkowo Wróblewski poprosił MSW o dwunastomiesięczny urlop bezpłatny liczony od 1 października $1921 \mathrm{r}^{61}$

Wróćmy do obsadzenia katedry. Komisja obradowała w lekko zmienionym składzie: przewodniczący Parczewski, referent komisji Komarnicki, członek Zawadzki. Po wysłaniu zapytań w tzw. ankiecie profesorskiej - wg art. 42 ustawy z 13 lipca 1920 r. o szkołach akademickich - i odczekaniu ustalonego dwumiesięcznego okresu Rada na wniosek dziekana 29 listopada 1922 r. poruczyła komisji przygotowanie referatu ${ }^{62}$. Był gotowy 6 grudnia 1922 r. Dowiadujemy się z niego, że na ankietę odpowiedział tylko Józef Jan Bossowski z Uniwersytetu w Poznaniu, który wskazał Wróblewskiego, podkreślając, że „bardziej odpowiedniej siły naukowej do objęcia katedry w Wilnie wskazać nie może"63. Być może pozostali profesorowie, do których wysłana została ankieta, nie odpisali „dyplomatycznie”; nie chcąc być oficjalnie przeciwko zaproponowaniu „młodego” Glasera na uniwersytecką katedrę. Następnie komisja w referacie wypowiedziała się o dorobku kandydata i rocznym jego pobycie w Wilnie jako zastępcy profesora. Ocena ta wypadła bardzo dobrze, a członkowie wyrażali się w samych superlatywach. Podkreślono wydanie dwóch prac: przywołanej już publikacji Przestępstwa tłumu (Wilno 1922) oraz Wstępu do polityki kryminalnej (Wilno 1922).

\begin{abstract}
Obie prace [...] cechuje jasność i przystępność wykładu. Forma zwięzła i ścisła, nie pozostawia niedomówień, rozwijanie swych myśli za pomocą przejrzystych konstrukcji - oto cechy obu tych prac, cechy, stanowiące dowód, iż p[an] WRÓBLEWSKI posiada uzdolnienia niezbędne dla wykładającego. [...] Należy podnieść wybitny dar jasnego wykładu oraz umiejętność prowadzenia prac seminaryjnych, co widoczne z zainteresowania, jakie obudziło wśród słuchaczy prowadzone przez kandydata seminarium i liczby prac członków seminarium ${ }^{64}$.
\end{abstract}

Tego samego dnia referat został przedstawiony Radzie Wydziałowej, która jednocześnie poparła zawarte w nim wnioski. Mianowicie zwrócono się do Senatu Akademickiego USB, aby ten wyjednał w MWRiOP nominację ${ }^{65}$. Pismo zostało do Warszawy wysłane 14 grudnia 1922 r. Ministerstwo poprosiło jednak o jego uzupełnienie. Wówczas z Wilna nadesłano akta osobowe, jak curriculum vitae z planem studiów i złożonymi egzaminami, thumaczenie dyplomu, nostryfikację tegoż w Krakowie, nominację na próbną służbę w MSW z 6 lutego 1919 r. oraz na referenta z 1 sierpnia 1919 r. i starszego referenta

${ }^{60}$ LCVA, f. 175, op. 13, spr. 339, protokół z 11 maja 1922 r. Cf. LCVA, f. 175, op. 2(VI)B, spr. 206, odpis protokołu posiedzenia Rady Wydziałowej z 11 maja 1922 r.

${ }^{61}$ LCVA, f. 175, op. 1(I)Bb, spr. 786, prośba B. Wróblewskiego z 21 września 1921 r. Ministerstwo nie przychyliło się do tej prośby, aby nie czynić precedensów. Jeżeli po porzuceniu profesury Wróblewski, jako wybitna siła prawnicza, zechciałby wrócić do pracy w MSW to nikt nie czyniłby mu przeszkód. Zob. ibidem, notatka naczelnika wydziału osobowego z 23 września $1921 \mathrm{r}$.

${ }^{62}$ LCVA, f. 175, op. 2(VI)B, spr. 28, protokół z 29 listopada 1922 r.

${ }^{63}$ LCVA, f. 175, spr. 2(VI)B, spr. 55, wniosek z 11 grudnia 1922 r.

${ }^{64}$ Ibidem.

${ }^{65}$ LCVA, f. 175, op. 2(VI)B, spr. 28, protokół z 6 grudnia 1922 r.; f. 175, op. 1(I)Bb, spr. 786, pismo W. Zawadzkiego z 7 grudnia 1922 r.; odpis pisma A. Parczewskiego z 14 grudnia 1922 r.; f. 175, spr. 2(VI)B, spr. 55, odpis pisma W. Zawadzkiego z 7 grudnia 1922 r. 
z 9 czerwca 1920 r. tamże, podziękowanie Ministra Spraw Wewnętrznych z 12 lutego 1920 r. za pracę oraz zwolnienie ze służby w resorcie z 8 grudnia 1921 r. $^{66}$ Dnia 16 marca 1923 r. Prezydent Rzeczypospolitej Stanisław Wojciechowski zamianował Wróblewskiego na nadzwyczajną katedrę prawa i procesu karnego WPiNS USB. Do obowiązków profesorskich należało prowadzenie badań, odbywanie wykładów i ćwiczeń w liczbie co najmniej pięciu godzin wykładów i dwóch godzin ćwiczeń tygodniowo lub w wymiarze innym, zakładając, że dwie godziny ćwiczeń to jedna godzina wykładu, kierownictwo seminarium połączonego z katedrą i sprawowanie wszelkich czynności akademickich. Objęcie katedry nastąpiło 1 kwietnia 1923 r. ${ }^{67}$

Względny spokój w pracy naukowej Wróblewskiego w Wilnie trwał trzy lata. W drodze urzędowej 9 czerwca 1926 r. przesłał on prośbę o zwolnienie ze wszystkich stanowisk $^{68}$. Dnia 11 czerwca 1926 r. kwestią tą zajmowała się Rada WPiNS. Dziekan przedstawił prośbę Wróblewskiego o dymisję z początkiem roku akademickiego 1926/27 (dzisiaj powiedzielibyśmy- z końcem roku 1925/26). Motywem, który skłonił profesora do takiego kroku, było ,[...] subiektywnie przez niego odczuwane nieprzychylne względem niego stanowisko Członków Wydziału”. Po dyskusji, w tajnym głosowaniu w posiedzeniu nie brał udziału zainteresowany - większością dziewięciu głosów (przy jednym wstrzymującym się) uchwalono, że ustąpienie będzie ciężką stratą dla Wydziału. Większością ośmiu za, przy jednym przeciw i jednym wstrzymującym się uchwalono, aby poprosić Eugeniusza Waśkowskiego, Zawadzkiego i Mieczysława Gutowskiego o podjęcie kroków celem skłonienia Wróblewskiego do cofnięcia dymisji ${ }^{69}$. Pertraktacje komisji pojednawczej nic nie dały i Wróblewski nie zmienił decyzji. Rada uchwaliła, by poczekać z rozpoczęciem procedury obsadzenia katedry aż do czasu przyjęcia, bądź nie, dymisji przez Prezydenta Rzeczypospolitej ${ }^{70}$. Minister Wyznań Religijnych i Oświecenia Publicznego wobec faktu, że Wróblewski nie podał konkretnych motywów, którymi się kierował, składając podanie, oraz wobec jednoznacznej opinii Rady, która skonstatowała, że jego ustąpienie z katedry byłoby ciężką stratą dla Wydziału, odmówił przedłożenia podania Głowie Państwa ${ }^{71}$.

W tym samym roku miał miejsce również pewien incydent. Na sali rozpraw sądowych 20 listopada 1926 r., gdzie Wróblewski występował w roli eksperta, adwokat Niedzielski w swojej mowie postawił pewne zarzuty profesorowi. Dziekan WPiNS USB poprosił o przedstawienie sprawozdania z incydentu, odtworzenia mowy, a także przedstawienia, jakiego zadośćuczynienia zażądał profesor ${ }^{72}$.

${ }^{66}$ LCVA, f. 175, op. 1(I)Bb, spr. 786, odpis pisma dziekana z 11 stycznia 1923 r.; f. 175, spr. 2(VI)B, spr. 55, odpis pisma dziekana z 11 stycznia $1923 \mathrm{r}$.

${ }^{67}$ LCVA, f. 175, op. 1(I)Bb, spr. 786, odpis nominacji z 14 kwietnia 1923 r.; f. 175, op. 14, spr. 600, odpis nominacji z 14 kwietnia 1923 r.; f. 175, spr. 2(VI)B, spr. 55, odpis nominacji z 14 kwietnia 1923 r.

${ }^{68}$ LCVA, f. 175, spr. 2(VI)B, spr. 55, prośba B. Wróblewskiego z 9 czerwca 1926 r.; f. 175, op. 1(I)Bb, spr. 786, pismo E. Waśkowskiego z 17 czerwca 1926 r.; odpis pisma do MWRiOP z 13 lipca 1926 r.

${ }^{69}$ LCVA, f. 175, op. 2(VIIB), spr. 29, protokół z 11 czerwca 1926 r.

70 Ibid., protokół z 18 czerwca $1926 \mathrm{r}$.

71 LCVA, f. 175, spr. 2(VI)B, spr. 55, odpis pisma A. Sujkowskiego z 9 września 1926 r.

72 Ibid., odpis pisma dziekana z 26 listopada 1926 r. Dnia 20 listopada 1926 r. przed Sądem Okręgowym w Wilnie była rozpoznawana sprawa Smoleńskiego-Karnickiego, gdzie w charakterze biegłego występował Wróblewski. „W odpowiedzi na wywody prof. Wróblewskiego jeden z obrońców p. adw. Niedzielski, mówiąc o samowolnem wymierzeniu sprawiedliwości przez świadka Dzierdziejewskiego oskarżonemu i powiedziawszy, że świadek ten był w towarzystwie dwóch swoich bratanków - studentów Uniwersytetu Stefana 


\section{Katedra procesu karnego (II katedra prawa i procesu karnego)}

Na posiedzeniu 9 czerwca 1923 r. Rada WPiNS USB wybrała komisję do obsadzenia katedry nadzwyczajnej procedury karnej w składzie: dziekan Zawadzki, profesorowie Komarnicki i Wróblewski oraz zastępca profesora Kazimierz Petrusewicz starszy ${ }^{73}$. Dziekanat wysłał prośby o opinię do Warszawy, Krakowa, Lwowa i Poznania 18 października $1923 \mathrm{r}^{74}$ Spłynęły dwie odpowiedzi. Ponownie z obowiązku wywiązał się Uniwersytet w Poznaniu. Józef Jan Bossowski odpisał, iż najlepszym kandydatem jest docent UJ oraz profesor Uniwersytetu w Lublinie Glaser ${ }^{75}$. Z UJ odpisał Krzymuski, proponując primo loco Reinholda ${ }^{76}$, docenta UJ i profesora tytularnego, autora obszernego studium nad nowelą o postępowaniu uproszczonym w sprawach o zbrodnie i występki (Nowela do procedury karnej o postępowaniu uproszczonem, Kraków 1920), secundo loco Glasera, którego „polecić [...] mogę jako prawnika bardzo zdolnego, a przytem pełnego zamiłowania do badań naukowych i talentu do jasnego i ścisłego rozumowania"77. Widać, że Krzymuski już całkowicie przekonał się do Glasera, „tego młodego wyhabilitowanego docenta". Opierając się na tych opiniach, po posiedzeniu komisji 12 grudnia 1923 r. Wróblewski przygotował referat, który był gotowy 13 grudnia $1923 \mathrm{r}$. Opowiedziano się w nim - ze względu na to, że Glasera wskazało dwóch profesorów właśnie za kandydaturą uczonego z Lublina i docenta $\mathrm{UJ}^{78}$. Przedstawiono w nim dorobek naukowy kandydata, w tym szczególną uwagę zwrócono na pracę Kompetencja sąów przysięglych (Lublin 1923), jedną z najważniejszych w jego dorobku i dodatkowo dotyczącą tej samej dziedziny wiedzy, jaką zajmowała się rzeczona katedra ${ }^{79}$. Tego dnia wniosek komisji został przedstawiony Radzie Wydziałowej, która uchwaliła powołanie na katedrę procedury karnej w charakterze nadzwyczajnego profesora Glasera ${ }^{80}$. Zostało

Batorego i że to było polowanie z kijami w nocy na człowieka - użył słów: «Łagodzącą okolicznością dla nich (t.j. studentów), iż wzięli udział w tej wyprawie jest to, że są studentami tutejszego Uniwersytetu i słyszą z ust swego profesora z wyżyn katedry, że tak postępować wolno». W dalszym ciągu swego przemówienia tenże p. adw. Niedzielski wypowiedział się: «To było targnięcie bezprawne, co nawet p. profesor Uniwersytetu Stefana Batorego był tak wspaniałomyślny, że przyznał»”. Zob. Kurjer Wileński, 25 listopada 1926, nr 273 (721). O wileńskiej adwokaturze zob. Tarkowski, Adwokatura wileńska, 127 i nast.

${ }^{73}$ LCVA, f. 175, op. 2(VI)B, spr. 206, odpis protokołu posiedzenia Rady Wydziałowej z 9 czerwca 1923 r. Zob. Tarkowski, Wydziat Prawa i Nauk Społecznych, 103 i n.

74 LCVA, f. 175, op. 2(VI)B, spr. 206, odpis listów z 18 października 1923 r.

75 Ibid., list J.J. Bossowskiego z 28 października 1923 r.

76 Zob. Dziadzio, „Józef Reinhold”, 263 i nast.

77 LCVA, f. 175, op. 2(VI)B, spr. 206, list E. Krzymuskiego z 12 listopada 1923 r.

78 S. Glaser, po habilitacji w Krakowie, gdzie otrzymał urlop, objął wykłady w Lublinie na tamtejszym katolickim Uniwersytecie, jako zastępca profesora na nadzwyczajnej katedrze prawa i procesu karnego (1 października 1920 r. - 30 września 1921 r.), a następnie profesor nadzwyczajny (1 października 1921 r. - 30 września 1924 r.). W latach 1922/1923 - 1923/1924 pełnił funkcję dziekana Wydziału Prawa i Nauk Społeczno-Ekonomicznych. Zob. Gałązka, ,Stefan Antoni Glaser”, 63-6; Gałązka, „Stefan Glaser”, $139-48$.

79 LCVA, f. 175, op. 2(VI)B, spr. 9, referat B. Wróblewskiego z 13 grudnia 1923 r.; f. 175, op. 1(I)Bb, spr. 99, odpis referatu B. Wróblewskiego z 13 grudnia $1923 \mathrm{r}$.

${ }^{80}$ LCVA, f. 175, op. 2(VI)B, spr. 28, protokół z 13 grudnia $1923 \mathrm{r}$. 
wysłane pismo do Senatu Akademickiego USB o zaakceptowanie uchwały i przedstawienie oficjalnego pisma do Prezydenta o mianowanie ${ }^{81}$.

Od 1 stycznia 1924 r. Glaser został jednak, w myśl wniosku Rektoratu, powołany na zastępcę profesora ${ }^{82}$. Musiał to być wcześniejszy zamysł wileńskiej uczelni. Istotnie 17 stycznia 1924 r. zostało wysłane do Warszawy pismo, aby do czasu załatwienia nominacji MWRiOP powołało Glasera w charakterze zastępcy profesora ${ }^{83}$. Glaser został nominowany na katedrę procedury karnej w Wilnie postanowieniem Prezydenta niewiele ponad miesiąc później, 28 lutego 1924 r. ${ }^{84}$

\section{Frakcja Wróblewskiego kontra frakcja Glasera na wileńskim fakultecie prawniczym}

Rozpoczynając swoje wspomnienia, Glaser skonstatował, że ,[...] Wilno, stało się po zamachu stanu Piłsudskiego w maju 1926 r., pepinierią sanacji, głównie - choć nie wyłącznie - na terenie naukowym" 85 . Sympatykami obozu rządowego byli na terenie WPiNS m.in. Stefan Ehrenkreutz i Wróblewski. Na przeciwnym biegunie stał Glaser. Konflikt personalny pomiędzy dwoma karnistami, przedstawicielami przeciwnych obozów politycznych dał się zauważyć pod koniec 1930 r., kiedy to USB - za przykładem UJ, choć później - chciał zaprotestować przeciwko aresztowaniu posłów opozycyjnych w nocy z 9 na 10 grudnia 1930 r. Zostało z tego powodu zwołane Zgromadzenie Ogólne Profesorów pod przewodnictwem Mariana Zdziechowskiego, który został o to przez Glasera poproszony ${ }^{86}$. Według Bronisława Żongołłowicza uczynił to Władysław Dziewulski, gdyż rektor Aleksander Januszkiewicz się uchylił ${ }^{87}$. Jak zapisał podsekretarz stanu w MWRiOP: „Głównym menerem był Glaser, replikował mu Wróblewski, że mogą poszkodowani w Brześciu wytoczyć proces cywilny o odszkodowanie"88.

Początek sporu personalnego pomiędzy Wróblewskim a Glaserem miał swoją genezę kilka lat wcześniej. Z biegiem czasu przerodził się on w powstanie dwóch stronnictw (frakcji) na WPiNS. Mówię tutaj (zaburzając nieco chronologię pracy) o sporze przy wyborze dziekana na kolejną kadencję (1932/33) u schyłku roku akademickiego 1931/32 na posiedzeniu Rady 18 czerwca 1932 r.:

[...] Na Wydziale Prawa z powodu dwóch partii: Wróblewskiego i Glasera, jako kandydatów na dziekanów, otrzymał osiem głosów Ehrenkreutz, zrzekł się wyboru. W następnych głosowa-

${ }^{81}$ LCVA, f. 175, op. 1(I)Bb, spr. 99, pismo W. Zawadzkiego z 27 grudnia 1923 r.; f. 175, op. 2(VI)B, spr. 9, odpis pisma W. Zawadzkiego z 17 grudnia $1923 \mathrm{r}$.

${ }^{82}$ LCVA, f. 175, op. 2(VI)B, spr. 9, odpis pisma MWRiOP z 25 stycznia 1924 r.

83 LCVA, f. 175, op. 1(I)Bb, spr. 99, odpis pisma do MWRiOP z 17 stycznia 1924 r.

${ }^{84}$ Ibid., pismo B. Miklaszewskiego z 1 kwietnia 1924 r.; f. 175, op. 2(VI)B, spr. 9, odpis postanowienia z 1 kwietnia 1924 r. Tak późna data wynikała z faktu, iż w pierwszym dokumencie, z 18 marca 1924 r., wkradł się błąd, który trzeba było sprostować.

${ }^{85}$ Glaser, Urywki wspomnień, 11.

86 Ibid., s. 18 i nast.

87 Żongołłowicz, Dzienniki 1930-1936, 104.

${ }^{88}$ Ibid. 
niach głosy się tak rozbiły, że ani Glaser, ani Wróblewski nie mieli większości. Żadnego wyjścia. Wówczas urządzili przerwę, namówili Zawadzkiego, aby pozwolił na siebie głosować, ale wyboru nie przyjął. Zgodził się, został po przerwie wybrany, zrzekł się wyboru, wówczas w drugim głosowaniu wybrano ośmioma głosami Ehrenkreutza, który wybór przyjął i został coś czwarty rok dziekanem, gdyż inaczej wydział zostałby bez dziekana ${ }^{89}$.

Ostatecznie dziekanem został wybrany Jerzy Panejko ${ }^{90}$. Powróćmy do zasadniczego tematu... 31 maja 1927 r. Rada Wydziałowa wybrała komisję w składzie: dziekan Komarnicki, członkowie prodziekan Waśkowski, Jerzy Lande, Glaser i Wróblewski, celem rozpatrzenia sprawy przemianowania katedry procesu karnego na de facto II katedrę prawa i procesu karnego ${ }^{91}$. Komisja zebrała się 8 czerwca 1927 r. i pod nieobecność Wróblewskiego, który zakomunikował pisemnie swoje negatywne stanowisko, komisja jednogłośnie uchwaliła wystąpienie $\mathrm{z}$ wnioskiem o przemianowanie katedry, a referat poruczono Landemu ${ }^{92}$. W swoim liście Wróblewski skonstatował, że utworzenie II katedry prawa i procedury karnej jest sprzeczne z memoriałem Rady Wydziałowej, na podstawie którego katedra procedury karnej w 1923 r. powstała. Dodatkowo kreowanie II katedry zwiększyłoby stan katedr tegoż przedmiotu w stosunku do innych uniwersytetów $\mathrm{i}$ - jak dobitnie autor listu stwierdził - „z tych względów wypowiadam się przeciwko tworzeniu II-ej katedry prawa karnego" ${ }^{\text {93. }}$. Nie do końca Wróblewski miał tu rację, o czym jeszcze niżej.

Niemniej referat był gotowy na następny dzień. Komisja, pod nieobecność Wróblewskiego, który w ten sposób manifestował swoje negatywne stanowisko, przychyliła się do referatu Landego i jednomyślnie uchwaliła, by zwrócić się do Rady Wydziałowej z wnioskiem o wystąpienie do MWRiOP o przemianowanie katedry procedury karnej na II katedrę prawa i procedury karnej. W drugiej części posiedzenia, po opuszczeniu obrad przez Glasera, Komisja na wniosek Komarnickiego uchwaliła, by zaproponować Glasera na nadzwyczajną katedrę, ale już prawa i procesu karnego ${ }^{94}$. Tego samego dnia, 9 czerwca 1927 r., obradowała Rada Wydziałowa, która - pod nieobecność Wróblewskiego i przy wstrzymującym się głosie Zawadzkiego - całkowicie podzieliła wnioski komisji ${ }^{95}$. Senat Akademicki, który musiał zaaprobować uchwałę Rady, poprosił o wyjaśnienia, a po ich przedstawieniu ponownie Rada 28 czerwca 1927 r., powtórzyła swoją uchwałę z 9 czerwca i jeszcze raz przedstawiła ją Senatowi. Upadł wówczas wniosek Zawadzkiego o odesłanie sprawy z powrotem do komisji celem przedstawienia nowego referatu. Większość zdobył wniosek dziekana Komarnickiego o ponowne przedstawienie sprawy Senatowi ${ }^{96}$. W przesłanym Senatowi Akademickiemu wyjaśnieniu czytamy m.in., iż Wróblewski, mimo że był członkiem komisji, nie brał w jej pracach

89 Ibid., s. 180.

${ }^{90}$ LCVA, f. 175, op. 2(VI)B, spr. 138, protokół z 18 czerwca 1932 r.

91 LCVA, f. 175, op. 2(VII)B, spr. 29, protokół z 31 maja 1927 r.

92 LCVA, f. 175, op. 2(VI)B, spr. 206, protokół posiedzenia komisji z 8 czerwca 1927 r.

93 Ibid., list B. Wróblewskiego z 7 czerwca 1927 r.

94 Ibid., protokół posiedzenia komisji z 9 czerwca 1927 r.

95 LCVA, f. 175, op. 2(VIIB), spr. 29, protokół z 9 czerwca 1927 r. Cf. LCVA, f. 175, op. 2(VI)B, spr. 206, odpis pisma dziekana z 10 czerwca 1927 r.; f. 175, op. 2(VI)B, spr. 9, odpis pisma dziekana z 10 czerwca 1927 r.; f. 175, op. 1(I)Bb, spr. 99, pismo W. Komarnickiego z 10 czerwca 1927 r.

${ }^{96}$ LCVA, f. 175, op. 2(VIIB), spr. 29, protokół z 28 czerwca 1927 r. Cf. LCVA, f. 175, op. 2(VI)B, spr. 206, odpis pisma dziekana z 30 czerwca 1927 r.; f. 175, op. 2(VI)B, spr. 9, odpis pisma dziekana z 30 
i posiedzeniach udziału. Swoje poglądy - negatywne - przedstawił w liście z 7 czerwca 1927 r. i zajętego raz stanowiska nie zmienił. Dziekan nadal jednak czuł się w obowiązku sprostować to stanowisko, jako niezbyt ścisłe. Tłumaczenie, że przemianowanie katedry procedury karnej na katedrę prawa i procedury karnej jest sprzeczne z uchwałą Rady Wydziałowej w przedmiocie kreowania tej pierwszej było o tyle nielogiczne, iż przyjmując takie stanowisko, żadna reforma, nawet najbardziej słuszna, nie mogłaby być przeprowadzona, bo z samej natury byłaby sprzeczna ze stanem obowiązującym, wcześniejszymi uchwałami itd. Decyzja o kreowaniu katedry procedury karnej wynikała li tylko z faktu, że po pierwsze w trakcie wieloletnich doświadczeń ograniczanie drugiej katedry tylko do procedury było niekorzystne z naukowego punktu widzenia, po drugie, w momencie ogłaszania ankiety mającej na celu znalezienie odpowiedniej osoby do kierowania katedrą zachodziła obawa, że takowej - od prawa karnego i procedury karnej - może nie być łatwo odnaleźć. Co się zaś tyczy drugiego zarzutu Wróblewskiego, że dwie katedry na jednym uniwersytecie byłyby sprzeczne ze stanem obowiązującym na innych uczelniach, dziekan tłumaczył, że było wręcz odwrotnie. Podawał za przykład Kraków (Krzymuski i Reinhold) i Lwów (Makarewicz i Julian Nowotny) - w kraju, a za granicą - dowodził, że katedr łącznych prawa materialnego i formalnego było znacznie więcej, i to na jednym uniwersytecie. Dodatkowo nigdzie te katedry nie były ograniczone tylko do prawa karnego lub procedury karnej ${ }^{97}$. Ostatecznie minister Kazimierz Świtalski przychylił się do wniosku Rady Wydziałowej 29 sierpnia 1928 r. ${ }^{98}$, a prezydent wydał postanowienie 4 grudnia 1928 r. ${ }^{99} \mathrm{~W}$ ten sposób w Wilnie - o czym wspominał już Wróblewski - istniały dwie nadzwyczajne katedry prawa i procesu karnego. Sytuacja taka nie miała miejsca - prawdopodobnie z wyjątkiem Lwowa oraz Krakowa - na żadnym uniwersytecie. I tutaj - jak zaznaczyłem - nie do końca Wróblewski miał rację. Wydział Prawa i Umiejętności Politycznych UJK posiadał dwie katedry prawa i procesu karnego, ale ten stan wynikał nie tyle z ,dobrodziejstwa inwentarza”, ile z powodu dwujęzyczności uczelni z czasów austriackich. Jedną katedrę piastował Makarewicz, a drugą Stebelski. Po śmierci tego ostatniego 24 września 1923 r. katedra nie została obsadzona, opłacany był z jej kredytów Nowotny, a w 1933 r. została zwinięta ${ }^{100}$. Kraków miał jedną katedrę, na której profesorem był Krzymuski. Druga - opuszczona przez Makarewicza - wakowała, a z jej kredytów opłacany był m.in. profesor tytularny, bez katedry, docent Reinhold. Wykłady prowadził wyhabilitowany docent Władysław Wolter, a procedura obsadzenia wakującej katedry - przygotowana tak naprawdę „pod niego” - została wdrożona w 1927 r. Powszechnie uważa się, że Wolter objął katedrę po Krzymuskim, co jednak wynika ze smutnego faktu śmierci tego ostatniego w Ostendzie. Gdyby nie ta okoliczność, w Krakowie byłoby dwóch profesorów i tym samym dwie obsadzone katedry $^{101}$.

czerwca 1927 r.; f. 175, op. 1(I)Bb, spr. 99, pismo W. Komarnickiego z 30 czerwca 1927 r.; f. 175, op. 1(I)Bb, spr. 99, pismo do MWRiOP z 22 lipca 1927 r.

${ }^{97}$ LCVA, f. 175, op. 2(VI)B, spr. 206, pismo dziekana (brak daty).

${ }_{98}$ LCVA, f. 175, op. 1(I)Bb, spr. 99, pismo K. Świtalskiego z 29 sierpnia 1928 r.; f. 175, op. 2(VI)B, spr. 206, odpis pisma K. Świtalskiego z 29 sierpnia 1928 r.

${ }_{99}$ LCVA, f. 175, op. 1(I)Bb, spr. 99, odpis pisma K. Świtalskiego z 17 grudnia 1928 r.; f. 175, op. 2(VI)

B, spr. 9, odpis pisma K. Świtalskiego z 17 grudnia 1928 r.

${ }^{100}$ Mudryj, „Stebelski Piotr”, 38-40.

101 Żukowski, Dzieje Wydziału Prawa, 263-73. 
Na rok akademicki 1927/1928 Glaser otrzymał roczny płatny urlop bez dodatku za kierownictwo seminarium i bez stypendium na prace naukowe i biblioteczne za granicą $^{102}$. Wróblewski zaś na rok akademicki 1929/1930 otrzymał urlop i zasiłek MWRiOP w wysokości 600 złotych miesięcznie oraz dodatek 1200 złotych na podróże i dojazdy „[...] do zwiedzanych przezeń Zakładów Karnych"103. Podczas tego urlopu, poza owym zwiedzaniem, profesor kompletował bibliotekę seminaryjną, a także korespondencyjnie nadzorował prace swoich studentów, zwłaszcza tych bardziej zaawansowanych. Dlatego też MWRiOP zachowało mu wypłacenie dodatku za kierownictwo seminarium ${ }^{104}$. Dnia 31 grudnia 1929 r. MWRiOP przyznało mu dodatkowe 5000 złotych na dalsze studia kryminologiczne za granicą ${ }^{105}$. Na rok akademicki 1929/30 MWRiOP zatwierdził dodatkowo, na podstawie uchwały Rady Wydziałowej z 25 czerwca 1929 r., Glasera jako zastępcę profesora na wakującej katedrze teorii i filozofii prawa, po odejściu Landego do Krakowa $^{106}$. Zastępstwo było corocznie odnawiane; na rok 1929/1930 ${ }^{107}$, 1930/193108 oraz 1931/1932 ${ }^{109}$. Od roku 1932/33 Glaser prowadził wykłady zlecone z teorii prawa, po niezaakceptowanej przez MWRiOP propozycji przekształcenia katedry teorii i filozofii prawa w katedrę filozofii prawa ${ }^{110}$.

W 1930 r. Rada WPiNS rozpoczęła procedurę „uzwyczajnienia” obu profesorów prawa i procesu karnego. Uchwałą tejże Rady z 22 marca 1930 r. Waśkowskiemu został powierzony referat w sprawie ,uzwyczajnienia” Glasera, a Komarnickiemu w takiej samej kwestii, ale dotyczącej Wróblewskiego ${ }^{111}$. Sprawy te były traktowane łącznie, aż do 5 czerwca 1930 r., kiedy to Waśkowski przedstawił referat dotyczący Glasera, Komarnicki natomiast złożył rezygnację z przygotowania takowego dla Wróblewskiego. Trudno wywnioskować, dlaczego tak się stało, że przyjaciel z czasów gimnazjum i studiów w Dorpacie zrezygnował z referatu. Być może zadziałały tutaj kwestie polityczne. Komarnickiemu jako posłowi na Sejm z ramienia Związku Ludowo-Narodowego nie było po drodze ze zwolennikiem obozu rządzącego, za jakiego uchodził Wróblewski (o czym była mowa wcześniej). W związku z tym referat dotyczący kwalifikacji naukowych Wróblewskiego został powierzony Panejce, który przedstawił sprawę ustnie ${ }^{112}$. Na tym posiedzeniu Rada zwróciła się do Senatu Akademickiego o wyjednanie nomina-

${ }^{102}$ LCVA, f. 175, op. 2(VI)B, spr. 9, pismo ministra WRiOP z 5 marca 1927 r.; pismo MWRiOP z 16 listopada 1927 r. Wniosek o stypendium był ponawiany kilkakrotnie. Za każdym razem bez rezultatu.

103 LCVA, f. 175, spr. 2(VI)B, spr. 55, odpis pisma S. Ehrenkeutza z 25 kwietnia 1929 r.; f. 175, op. 1(I) Bb, spr. 786, pismo S. Ehrenkreutza z 25 kwietnia 1929 r.; odpis pisma Falkowskiego z 29 kwietnia 1929 r.

104 LCVA, f. 175, spr. 2(VI)B, spr. 55, odpis pisma S. Ehrenkreutza z 28 czerwca 1929 r.; odpis pisma W. Suchodolskiego z 5 września 1929 r.; f. 175, op. 1(I)Bb, spr. 786, pismo S. Ehrenkreutza z 28 czerwca 1929 r.; odpis pisma Falkowskiego z 8 lipca 1929 r.; pismo W. Suchodolskiego z 5 września 1929 r.

105 LCVA, f. 175, spr. 2(VI)B, spr. 55, odpis pisma W. Suchodolskiego z 31 grudnia 1929 r.; f. 175, op. 1(I)Bb, spr. 786, odpis pisma W. Suchodolskiego z 31 grudnia $1929 \mathrm{r}$.

${ }^{106}$ LCVA, f. 175, op. 2(VI)B, spr. 9, odpis pisma dziekana z 28 czerwca 1929 r.; odpis pisma W. Suchodolskiego z 20 lipca 1929 r. Zob. Sukiennicki, ,Legenda i rzeczywistość”, 36.

107 LCVA, f. 175, op. 2(VI)B, spr. 198, protokół posiedzenia Komisji z 25 czerwca 1929 r.

108 LCVA, f. 175, op. 2(VI)B, spr. 9, odpis pisma do S. Glasera z 8 września 1930 r.

109 Ibid., odpis pisma dziekana z 20 czerwca $1931 \mathrm{r}$.

110 Ibid., odpis pisma dziekana z 13 października 1932 r. Wiktor Sukiennicki miałby objąć zastępstwo na katedrze filozofii prawa, a S. Glaser prowadziłby wykłady zlecone z teorii prawa. Zob. LCVA, f. 175, op. 2(VI)B, spr. 198, protokół posiedzenia Komisji z 6 października $1931 \mathrm{r}$.

111 LCVA, f. 175, op. 2(VI)B, spr. 29, protokół z 22 marca 1920 r.

112 Ibid., protokół z 5 czerwca $1930 \mathrm{r}$. 
cji na profesora zwyczajnego dla Wróblewskiego ${ }^{113}$. Ten 6 czerwca 1930 r. przychylił się do wniosku Rady Wydziałowej i odpowiednie pismo zostało wysłane do Warszawy 11 czerwca 1930 r. ${ }^{114}$ Rada uchwaliła również, by zwrócić się do Senatu Akademickiego o zaakceptowanie uchwały i przesłanie do Warszawy wniosku o zamianowanie Glasera na katedrę nadzwyczajną, co stało się faktem 6 czerwca $1930^{115}$. Na kolejnym posiedzeniu 18 czerwca 1930 r. Rada uchwaliła, by przyspieszyć przemianowanie dwóch katedr $^{116}$. Dnia 21 czerwca 1930 r. Rada ponowiła wniosek o przyspieszenie ,uzwyczajnienia" obu profesorów nadzwyczajnych - Wróblewskiego i Glasera, których dorobek naukowy od czasu nominacji znacznie się powiększył ${ }^{117}$. Ministerstwo 20 czerwca 1930 r. poprosiło o uzupełnienie wniosku dotyczącego Wróblewskiego i przysłanie życiorysu, co też Rektorat uczynił 24 czerwca 1930 r. ${ }^{118}$ Sprawa Glasera stała się natomiast bezprzedmiotowa, gdyż Prezydent wydał postanowienie o przemianowaniu katedry nadzwyczajnej na zwyczajną już 20 września 1930 r. ${ }^{119}$ Postanowienie w sprawie drugiego profesora nosi datę 29 października 1930 r. ${ }^{120}$ Zatem na liście „starszeństwa profesorskiego" młodszy Glaser powinien być wymieniany przed starszym Wróblewskim.

Kiedy wydawało się, że nastąpiło ustabilizowanie sytuacji i współpraca czy chociaż wspólna egzystencja obu profesorów zaczną funkcjonować w miarę sprawnie i bez nieporozumień, decyzją MWRiOP z 25 września 1933 r. katedra Glasera wraz z funkcjonującym przy niej seminarium została zlikwidowana ${ }^{121}$. Tym samym, na podstawie rozporządzenia Prezydenta z 24 lutego 1928 r., minister Janusz Jędrzejewicz przeniósł Glasera w stan nieczynny ${ }^{122}$.

${ }^{113}$ LCVA, f. 175, spr. 2(VI)B, spr. 55, wniosek z 5 czerwca 1930 r.; f. 175, op. 1(I)Bb, spr. 786, pismo S. Ehrenkreutza z 6 czerwca 1930 r.; f. 175, spr. 2(VI)B, spr. 55, odpis pisma S. Ehrenkreutza z 6 czerwca $1930 \mathrm{r}$.

${ }^{114}$ LCVA, f. 175, op. 1(I)Bb, spr. 786, odpis pisma Falkowskiego z 11 czerwca 1930 r.

115 LCVA, f. 175, op. 2(VI)B, spr. 9, odpis pisma dziekana z 6 czerwca 1930 r.; f. 175, op. 1(I)Bb, spr. 99, pismo S. Ehrenkreutza z 6 czerwca 1930 r.; odpis pisma Falkowskiego z 11 czerwca 1930 r.

${ }^{116}$ LCVA, fond 175, opis 2VIB, sprawa 29, protokół z 18 czerwca $1930 \mathrm{r}$.

117 LCVA, f. 175, op. 2(VI)B, spr. 206, odpis pisma dziekana z 23 czerwca 1930 r.

${ }_{118}$ LCVA, f. 175, op. 1(I)Bb, spr. 786, brudnopis pisma z 29 czerwca $1930 \mathrm{r}$.

119 LCVA, f. 175, op. 2(VI)B, spr. 9, odpis pisma S. Czerwińskiego z 30 września 1930 r.

${ }^{120}$ LCVA, f. 175, op. 1(I)Bb, spr. 786, pismo J. Stypińskiego z 7 listopada 1930 r.; odpis pisma S. Czerwińskiego z 7 listopada 1930 r.; f. 175, op. 14, spr. 600, odpis pisma S. Czerwińskiego z 7 listopada 1930 r.; f. 175, spr. 2(VI)B, spr. 55, odpis pisma S. Czerwińskiego z 7 listopada $1930 \mathrm{r}$.

${ }^{121}$ Rozporządzenie MWRiOP o zwinięciu niektórych katedr i zakładów naukowych. Na wydziałach prawniczych zlikwidowano wówczas: na UJ katedrę ekonomii i polityki ekonomicznej, na USB II katedrę prawa i procesu karnego, na UJK I katedrę prawa rzymskiego, katedrę historii prawa polskiego, I katedrę ekonomii, II katedrę prawa i procesu sądowo-karnego, katedrę ogólnego i polskiego nowożytnego prawa politycznego, w Poznaniu II katedrę prawa administracyjnego. Z innych katedr prawniczych w pozostałych szkołach akademickich zwinięto katedrę ekonomii politycznej oraz katedrę organizacji pracy i przedsiębiorstw na Politechnice w Warszawie, katedrę prawoznawstwa oraz katedrę organizacji przedsiębiorstw przemysłowych na Akademii Górniczej w Krakowie. W zamian na USB powstało studium prawa litewskiego i miało być one zakładem z katedrą.

${ }^{122}$ LCVA, f. 175, op. 2(VI)B, spr. 9, odpis pisma J. Jędrzejewicza z 26 września 1933 r. Zwolnienie ze służby państwowej nastąpiło z dniem 30 września 1934 r. Zob. ibid., odpis pisma W. Jędrzejewicza z 27 października $1934 \mathrm{r}$. 
W ten sposób Glaser stał się 39-letnim emerytem, który „[... [ ze względu na okoliczności" poświęcił się adwokaturze, a w swojej działalności zajmował się głównie sprawami politycznymi ${ }^{123}$.

$\mathrm{Na}$ fakultecie prawniczym wileńskiej wszechnicy pozostał Wróblewski, który rozwijał się naukowo bardzo dobrze. Poza wykładami, do których był zobowiązany dekretem nominacyjnym, prowadził zajęcia z socjologii od początku drugiego trymestru 1930/31 $1^{124}$. W tymże roku akademickim, w przerwie międzytrymestralnej, wyjechał za granicę, gdzie zwiedzał więzienia w Brukseli (Forest) oraz Saint Gilles i centralne więzienie w Gandawie, a także pracował w laboratorium d'antropologie pénitentiare i zapoznał się z organizacją Le Service antropologie pénitentiare. Zdobytą wiedzę wykorzystał w pracy o wpływie prawa na moralność ${ }^{125}$. Pełnił funkcję dziekana Wydziału w latach akademickich 1934/35 - 1935/36 oraz prodziekana w roku 1936/37 (do 27 listopada 1936 r., kiedy to zrezygnował) ${ }^{126} .22$ grudnia 1934 r. Wróblewski został przez ministra mianowany na zastępcę przewodniczącego Wyższej Komisji Dyscyplinarnej dla profesorów szkół akademickich na lata 1934/35 - 1936/37127. Na pierwszy trymestr roku $1936 / 37$ otrzymał płatny urlop dla poratowania zdrowia ${ }^{128}$. Wykładał ponadto w Szkole Nauk Politycznych przy Instytucie Badawczym Europy Wschodniej w Wilnie ${ }^{129}$. Dnia 17 grudnia 1938 r. otrzymał brązowy medal „Za Długoletnią Służbę”"130.

\section{Wnioski i zakończenie}

Dnia 2 czerwca 1938 r. Wróblewski złożył na ręce dziekana wniosek o przywrócenie katedry procedury karnej. W swojej argumentacji przypomniał, że na podstawie uchwały Rady z 11 maja 1922 r. została od nowego roku akademickiego utworzona katedra procedury karnej, na co przystało MWRiOP. „W roku 1928 została ona ze względów personalnych przemianowana na II katedrę prawa i procesu karnego, w roku zaś 1933 skasowana [...]". Osiągnięcia naukowe, które legły u podstaw wniosku z 1922 r. po latach nie straciły na aktualności. Dodatkowo kodeks postępowania karnego uległ z powodów „nieumiejętnego opracowania” wielokrotnym nowelizacjom. Wróblewski podkreślał - na kanwie swoich doświadczeń naukowych - ,że w literaturze i praktyce coraz bardziej wybija[ła] się sprawa nie orzekania kary, a wykonywania kary”. Dlatego

${ }^{123}$ Glaser, Urywki wspomnień, 28-9.

${ }^{124}$ LCVA, f. 175, spr. 2(VI)B, spr. 55, odpis pisma do kwestury z 16 lutego $1931 \mathrm{r}$.

${ }^{125}$ Ibid., sprawozdanie B. Wróblewskiego z 29 maja 1931 r.

126 Żukowski, „Bronisław Wróblewski”.

${ }^{127}$ LCVA, f. 175, op. 1(I)Bb, spr. 786, odpis pisma W. Staniewicza z 29 grudnia 1934 r.; odpis pisma J. Jędrzejewicza z 22 grudnia $1934 \mathrm{r}$.

${ }_{128}$ Ibid., odpis pisma W. Świętosławskiego z 26 października 1936 r. Cf. LCVA, f. 175, spr. 2(VI)B, spr. 55, pismo W. Świętosławskiego z 26 października 1936 r. W 1937 r. korzystał B. Wróblewski kilkakrotnie z przedłużenia tego urlopu oraz z urlopu dziekańskiego. Zob. LCVA, f. 175, spr. 2(VI)B, spr. 55, odpis pisma W. Staniewicza z 27 stycznia 1937 r.; podanie B. Wróblewskiego z 3 marca 1937 r.

${ }^{129}$ Ilgiewicz, Instytut Naukowo-Badawczy Europy Wschodniej, 11 i nast.; Kornat, „Instytut Naukowo-Badawczy Europy Wschodniej”, 43-89.

${ }^{130}$ LCVA, f. 175, op. 1(I)Bb, spr. 786, informacja prorektora z 17 grudnia $1938 \mathrm{r}$. 
przyszły adwokat czy sędzia powinni gruntownie znać prawo karne materialne, proces karny, prawo karne wykonawcze i więziennictwo na tym samym poziomie. Należy więc wdrożyć postępowanie o przywrócenie samodzielnej katedry procedury karnej ${ }^{131}$. Rada Wydziałowa 11 czerwca 1938 r. w pełni poparła wniosek i uchwaliła zwrócenie się z wnioskiem do MWRiOP o reaktywowanie tej katedry ${ }^{132}$. Możemy zatem skonstatować, że Wróblewski również po latach nie zmienił zdania co do funkcjonowania dwóch katedr - pierwszej specjalizującej się tylko w prawie karnym, a drugiej w procedurze. Nie byłaby to jednak cała prawda. Wniosek Wróblewskiego został postawiony w czasie gdy Glasera nie było już na wileńskim fakultecie. I dodatkowo w duchu nie skłaniał się ku przywróceniu personalnej obsady katedry zamkniętej przed laty. Podstawy osobistego i politycznego sporu pomiędzy Wróblewskim a Glaserem w 1938 r. nie zniknęły. Usunięta została jedna strona tego konfliktu. Trzeba też dodać, że Wróblewski miał już upatrzonego kandydata na reaktywowaną katedrę. Z prawdopodobieństwem graniczącym z pewnością mowa o wyhabilitowanym nie bez przeszkód (podczas głosowania za nadaniem tytułu docenta i udzieleniem venia legendi Glaser złożył votum separatum) w 1932 r. Witoldzie Świdzie. Był on uczniem i współpracownikiem Wróblewskiego, zatrudnionym (od 1935 r.) na etacie adiunkta ${ }^{133}$.

$* * *$

Biogramy uczonych zajmujących się nauką prawa i procesu karnego są również pełne rozbieżności i sprzeczności. W samym tylko UJ możemy takie ,pary” wymienić:

1) Edmund Krzymuski i Józef Rosenblatt;

2) Edmund Krzymuski i Juliusz Makarewicz

3) Edmund Krzymuski i Józef Reinhold

Na gruncie wileńskim mieliśmy Wróblewskiego i Glasera. Kiedy w Krakowie młody Juliusz Makarewicz złożył - a nie przypuszczał nawet, że jego wniosek nie zyska akceptacji - pierwsze podanie o venia legendi, przy kolokwium ,ścięty” został przez klasyka Krzymuskiego. W Wilnie mieliśmy, zachowując pewne proporcje, podobny wypadek. Na bazie sporu Wróblewski-Glaser zapowiadająca się bardzo dobrze kariera młodego uczonego Witolda Świdy mogła zostać utopiona w bieli kart do głosowania z napisem NIE przy głosowaniu o udzieleniu venia legendi na Radzie WPiNS, a następnie przy zatwierdzeniu tejże uchwały przez Senat Akademicki. Jest to jednak wątek zasługujący na oddzielne omówienie.

$$
* * *
$$

Bronisław Wróblewski zmarł w Wilnie 26 sierpnia 1941 r. na atak serca bądź udar mózgu podczas rewizji jego wileńskiego mieszkania przez Niemców ${ }^{134}$. Pochowano go na cmentarzu Na Rossie ${ }^{135}$.

131 LCVA, f. 175, op. 2(VI)B, spr. 206, pismo B. Wróblewskiego z 2 czerwca 1938 r.

132 LCVA, f. 175, op. 2(VI)B, spr. 138, protokół z 11 czerwca 1938 r.

133 Tarkowski, „Świda Witold”, 551-3; Żukowski, „Świda Witold”, 216-9.

134 Pojawiająca się informacja, że byli to sowieccy funkcjonariusze NKWD jest nieprawdziwa.

135 Po zakończeniu II wojny światowej ukazała się książka autorstwa Bronisława Wróblewskiego Język prawny $i$ prawniczy, ze wstępem Władysława Woltera i Romana Ingardena (Kraków: Polska Akademia Umiejętności, 1948). Zamieszczono w niej bibliografię prac autora. 
Stefan Glaser opuścił Polskę po klęsce wrześniowej w 1939 r. Na uchodźstwie był m.in. posłem nadzwyczajnym i ministrem pełnomocnym w Królestwie Belgii ${ }^{136}$ oraz profesorem na polskim Wydziale Prawa przy Uniwersytecie w Oxfordzie, a po $1945 \mathrm{r}$. na uczelniach w Liège, Lowanium i Gandawie. Poświęcił się naukowo międzynarodowemu prawu karnemu, zdobywając w tej dziedzinie uznanie. Zmarł 30 kwietnia 1984 r. w Brukseli ${ }^{137}$.

\section{Bibliografia}

\section{Źródła archiwalne}

Archiwum Akt Nowych w Warszawie

Protokoły Posiedzeń Rady Ministrów, t. VII

Ministerstwo Wyznań Religijnych i Oświecenia Publicznego, sygn. 6703, Teczka personalna B. Wróblewskiego

Archiwum Katolickiego Uniwersytetu Lubelskiego

sygn. A-16, teczka personalna S. Glasera

Archiwum Uniwersytetu Jagiellońskiego w Krakowie

S II 226b, Katalog studentów dla Kwestury

S II 515, Album Universitatis Jagellonicae Cracoviensis ab anno 1893/94 - 1910/11

WF II 359. Katalog wydziałowy dla dziekana

WP II 138. Teczka habilitacyjna S. Glasera

WP II 542. Nostryfikacje dyplomów zagranicznych

Державний архів Львівської області (Państwowe Archiwum Obwodowe we Lwowie)

f. 26, op. 15, spr. 502, poz. 252, Księga protokołów egzaminów ścisłych na stopień doktora praw

Lietuvos Centrinis Valstybės Archyvas w Wilnie

f. 175, op. 1(I)Bb, spr. 99, Teczka personalna S. Glasera

f. 175, op. 1(I)Bb, spr. 786, Teczka personalna B. Wróblewskiego

f. 175, op. 2(VI)B, spr. 9, Teczka personalna S. Glasera

f. 175, op. 2(VI)B, spr. 28, Protokoły posiedzeń Rady Wydziału

f. 175, op. 2(VIIB), spr. 29, Protokoły posiedzeń Rady Wydziału

f. 175, spr. 2(VI)B, spr. 55, Teczka personalna B. Wróblewskiego

f. 175, op. 2(VI)B, spr. 138a, Protokoły posiedzeń Rady Wydziału

f. 175, op. 2(VI)B, spr. 198, Komisja w sprawie obsadzenia katedry teorii i filozofii prawa

f. 175, op. 2(VI)B, spr. 206, Komisja w sprawie obsadzenia II katedry prawa karnego

f. 175, op. 13, spr. 339, Protokoły posiedzeń Rady Wydziału

f. 175, op. 14, spr. 600, Teczka personalna B. Wróblewskiego

${ }^{136}$ Kwiecień, Wśród potępieńczych swarów, 13 i nast.

137 Ostatnio tym zagadnieniem zaczęli się zajmować Karolina Wierczyńska i Grzegorz Wierczyński. Zob. Wierczyńska, Wierczyński, "Stefan Glaser: Polish Lawyer”, 306-34. 


\section{Źródła drukowane}

Glaser, Stefan. Urywki wspomnień. Londyn: Odnowa, 1974.

Taubenschlag, Rafał. Pamiętnik z lat 1881-1947. Oprac. Przemysław Marcin Żukowski. Kraków (w przygotowaniu).

Żongołłowicz, Bronisław. Dzienniki 1930-1936. Oprac. Dorota Zamojska. Warszawa: Studium Europy Wschodniej Uniwersytetu Warszawskiego, 2004.

Żukowski, Przemysław Marcin. Dzieje Wydziału Prawa Uniwersytetu Jagiellońskiego w Krakowie w latach 1918-1939. Źródła. Kraków: Księgarnia Akademicka, 2017.

\section{Źródła prawa}

Rozporządzenie Ministra Wyznań Religijnych i Oświecenia Publicznego z 25 września 1933 r. o zwinięciu niektórych katedr i zakładów naukowych w szkołach akademickich (Dz.U. 1933 nr 71 poz. 527).

Ustawa z 13 lipca 1920 r. o szkołach akademickich (Dz.U.R.P. 1920 nr 72 poz. 494).

\section{Opracowania}

Baranowski, Krzysztof. Alternatywna edukacja w II Rzeczypospolitej. Wolna Wszechnica Polska. Warszawa: Towarzystwo Wolnej Wszechnicy Polskiej, 2001.

Barcik, Mieczysław, Cieślak, Adam, Gaszyński, Paweł, Grodowska-Kulińska, Danuta, Perkowska, Urszula i Żukowski, Przemysław Marcin. Corpus Studiosorum Universitatis Iagellonicae 1850/51-1917/18 3 (T-Ż), red. Krzysztof Stopka. Kraków: Księgarnia Akademicka, 2015.

Cieślak, Marian. „Stefan Glaser (1895-1984)”. Państwo i Prawo 40, z. 3 (1985): 104.

Cyuńczyk, Filip. „Wydział Prawa Uniwersytetu w Dorpacie i jego Polscy studenci”. Miscellanea Historico-Iuridica 13 (2014): 181-91.

Dąbrowski, Przemysław. Mutationes in doctrina iuris. Kwestia prac nad reforma uniwersyteckich studiów prawniczych w Polsce (1918-1939). Gdańsk: Wydawnictwo GSW, 2015.

Dziadzio, Andrzej. „Józef Reinhold (1884-1928) - „zapomniany” profesor prawa karnego Uniwersytetu Jagiellońskiego. Krakowskie Studia z Historii Państwa i Prawa 7, z. 2 (2014): 263-72.

Gałązka, Małgorzata. „Stefan Antoni Glaser”. W: Dziekani Wydziału Prawa, Prawa Kanonicznego i Administracji Katolickiego Uniwersytetu Lubelskiego Jana Pawła II, red. Antoni Dębiński, Wojciech S. Staszewski i Monika Wójcik, 63-6. Lublin: Wydawnictwo KUL, 2008.

Gałązka, Małgorzata, „Stefan Glaser”. W: Profesorowie prawa Katolickiego Uniwersytetu Lubelskiego, red. Antoni Dębiński, Wojciech S. Staszewski i Monika Wójcik, 139-48. Lublin: Wydawnictwo KUL, 2008.

Ilgiewicz, Henryka. Instytut Naukowo-Badawczy Europy Wschodniej oraz Szkoła Nauk Politycznych w Wilnie (1930-1939). Warszawa: Scholar, 2019.

Kita, Jarosław i Pytlas, Stefan. Profesorowie Uniwersytetu Łódzkiego w latach 1945-1994. Pro Memoria. Łódź: Wydawnictwo Uniwersytetu Łódzkiego, 1995.

Kolarzowski, Jerzy J. „Bronisław Wróblewski prekursor socjologii historycznej”. Studia Iuridica 34 (1997): 33-50.

Kolarzowski, Jerzy J. „Definicja i funkcje polityki kryminalnej w pracach Bronisława Wróblewskiego”. Studia Iuridica 31 (1996): 23-46. 
Koredczuk, Józef. „Nauka i nauczanie procesu karnego w Polsce w okresie międzywojennym”. W: Nauka i nauczanie prawa w dziejach, red. Tomasz Kruszewski, 117-40. Wrocław: Kolonia Limited, 2011.

Kornat, Marek. „Instytut Naukowo-Badawczy Europy Wschodniej w Wilnie (1930-1939) i jego wkład w rozwój polskiej sowietologii”. Kwartalnik Historyczny 107, z. 3 (2000): 43-89.

Kozłowska, Małgorzata. Życie dlutem wyżłobione. Twórczość Krystyny Wróblewskiej (1904-1994). Warszawa: Neriton, 2007.

Kurjer Wileński, 25 listopada 1926, nr 273 (721).

Kwiecień, Marcin. Wśród potępieńczych swarów. Prawne aspekty rozliczeń politycznych wśród uchodźstwa polskiego we Francji i Wielkiej Brytanii 1939-1943. Kraków: Księgarnia Akademicka, 2013.

Lewandowski, Henryk i Zirk-Sadowski, Marek. „Jerzy Wróblewski 1926-1990”. Państwo i Prawo 50, nr 10 (1990): 92-5.

Lityński, Adam. Wydziat Karny Komisji Kodyfikacyjnej II Rzeczypospolitej. Dzieje prac nad częścia ogólna kodeksu karnego. Katowice: Wydawnictwo Uniwersytetu Śląskiego, 1991.

Machovenko, Jevgenij, ed. Law Faculty of Vilnius University in 1641-2010. Vilnius: Vilnius University, 2011.

Michalski, Jan, red. Andrzej Wróblewski nieznany. Kraków: Galeria Zderzak, 1993.

Mudryj, Marian. „Stebelski Piotr”. W: Polski słownik biograficzny 43: 38-40.

Opałek, Kazimierz i Wolter, Władysław. Nauka filozofii prawa i prawa karnego w Polsce. Kraków: Wydawnictwo Polskiej Akademii Umiejętności, 1948.

Piechnik, Ludwik i Puchowski Kazimierz. Księga pamiątkowa ku czci 400-lecia założenia i 75 rocznicy wskrzeszenia Uniwersytetu Wileńskiego. Kraków: Wydawnictwo WAM, 1996.

Księga pamiatkowa ku uczczeniu CCCL rocznicy powstania $i$ wskrzeszenia Uniwersytetu Wileńskiego 2. Wilno: Wydawnictwo Uniwersytetu Stefana Batorego w Wilnie, 1929.

Pilch, Andrzej. Rzeczpospolita Akademicka. Studenci i polityka 1918-1933. Kraków: Księgarnia Akademicka, 1997.

Pluta, Przemysław. „Autorytety prawnicze z Uniwersytetu Stefana Batorego po zakończeniu II wojny światowej. Zarys życiowych losów". W: Wybitni prawnicy na przestrzeni wieków. red. Maciej Marszał i Jacek Przygodzki, 229-30. Wrocław, Wydawnictwo Uniwersytetu Wrocławskiego, 2006.

Przeniosło, Małgorzata. „Profesorowie Wydziału Prawa i Nauk Społecznych Uniwersytetu Stefana Batorego w Wilnie”. Kwartalnik Historii Nauki i Techniki 61, nr 2 (2016): 7-32.

Przeniosło, Małgorzata i Przeniosło, Marek. „Studia prawnicze na Uniwersytecie Stefana Batorego w Wilnie 1919-1939”. Wschodni Rocznik Humanistyczny 16, nr 4 (2019): 175-201.

Redzik, Adam. „Glaser Stefan Antoni”. W: Stownik biograficzny adwokatów polskich 3, z. 1: 113-5. Warszawa: Naczelna Rada Adwokacka, 2018.

Redzik, Adam i Kotliński, Tomasz J. Historia adwokatury. Warszawa: Naczelna Rada Adwokacka, 2012.

Smolana Krzysztof, oprac. Słownik biograficzny polskiej stużby zagranicznej 1918-1945 3. Warszawa: Ministerstwo Spraw Zagranicznych, 2010.

Sukiennicki, Wiktor. Legenda i rzeczywistość. Wspomnienia i uwagi o dwudziestu latach Uniwersytetu Stefana Batorego w Wilnie. Paryż: Instytut Literacki, 1967.

Tarkowski, Mikołaj. Adwokatura wileńska 1918-1939. Gdańsk: Arche, 2014.

Tarkowski, Mikołaj. „Świda Witold”. W: Stownik biograficzny adwokatów polskich. 3, z. 1, 5513. Warszawa: Naczelna Rada Adwokacka, 2018.

Tarkowski, Mikołaj. Wydział Prawa i Nauk Społecznych Uniwersytetu Stefana Batorego w Wilnie w latach 1919-1939. Gdańsk: Wydawnictwo GSW, 2015.

Tomaszewski, Jerzy. „Rząd Rzeczypospolitej Polskiej wobec projektu utworzenia Uniwersytetu Ukraińskiego we Lwowie". W: Ukraińska myśl polityczna w XX wieku, red. Michał Puła- 
ski. Zeszyty Naukowe Uniwersytetu Jagiellońskiego 1088, Prace Historyczne, z. 103 (1993): 116-7.

Wierczyńska, Karolina i Wierczyński, Grzegorz. „Stefan Glaser: Polish Lawyer, Diplomat and Scholar". W: The Dawn of a Discipline: International Criminal Justice and Its Early Exponents, eds. Immi Talgren and Frédéric Mégret, 306-34. Cambridge: Cambridge University Press, 2020.

Wróblewski, Bronisław. Język prawny i prawniczy. Kraków: Wydawnictwo Polskiej Akademii Umiejętności, 1948.

Żukowski, Przemysław Marcin. „Bronisław Wróblewski”. W: Poczet rektorów i dziekanów Uniwersytetu Stefana Batorego w Wilnie, red. Przemysław Marcin Żukowski. Warszawa (w przygotowaniu).

Żukowski, Przemysław Marcin. Dzieje Wydziału Prawa Uniwersytetu Jagiellońskiego w Krakowie w latach 1918-1939. Kraków: Księgarnia Akademicka, 2016.

Żukowski, Przemysław Marcin. „Pracownicy i absolwenci Uniwersytetu Jagiellońskiego w polskiej służbie zagranicznej”. Zeszyty Historyczne (Paryż) 165 (2008): 34-70.

Żukowski, Przemysław Marcin. Profesorowie Wydziału Prawa Uniwersytetu Jagiellońskiego 2 (1780-2012), red. Dorota Malec. Kraków: Wydawnictwo Uniwersytetu Jagiellońskiego, 2014. Żukowski, Przemysław Marcin. „Świda Witold”. W: Polski słownik biograficzny 51: 216-9. 